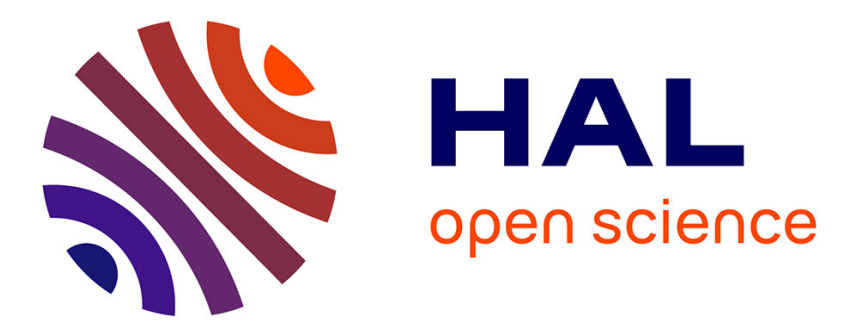

\title{
Archean Sanukitoid Gold Porphyry Deposits: A New Understanding and Genetic Model from the Lac Bachelor Gold Deposit, Abitibi, Canada
}

\author{
Noémie Fayol, Michel Jebrak
}

\section{- To cite this version:}

Noémie Fayol, Michel Jebrak. Archean Sanukitoid Gold Porphyry Deposits: A New Understanding and Genetic Model from the Lac Bachelor Gold Deposit, Abitibi, Canada. Economic Geology, 2017, 112 (8), pp.1913-1936. 10.5382/econgeo.2017.4534 . hal-02012053

\section{HAL Id: hal-02012053 \\ https://hal.science/hal-02012053}

Submitted on 14 Feb 2019

HAL is a multi-disciplinary open access archive for the deposit and dissemination of scientific research documents, whether they are published or not. The documents may come from teaching and research institutions in France or abroad, or from public or private research centers.
L'archive ouverte pluridisciplinaire HAL, est destinée au dépôt et à la diffusion de documents scientifiques de niveau recherche, publiés ou non, émanant des établissements d'enseignement et de recherche français ou étrangers, des laboratoires publics ou privés. 


\title{
Archean Sanukitoid Gold Porphyry Deposits: A New Understanding and Genetic Model from the Lac Bachelor Gold Deposit, Abitibi, Canada
}

\author{
Noémie Fayol ${ }^{1, \dagger}$ and Michel Jébrak ${ }^{1}$ \\ ${ }^{1}$ Département des Sciences de la Terre et de l'atmosphère, UQAM, CP 8888, succ. Centre-ville, Montréal, QC H3C 3P8, Canada
}

\begin{abstract}
In the Abitibi subprovince of the Superior craton, Canada, recognition of intrusion-related gold deposits is improving, but their formation remains poorly understood. The recently reopened Lac Bachelor deposit in the northeastern part of the Abitibi subprovince is located on the edges of a syenitic complex, and this deposit is an example of a highly fractionated, Fe-Mg-poor, quartz-syenite to alkali-granite centered deposit. Gold is associated with pyrite in localized alkaline, fluorine, and hematite-rich metasomatized zones in magnetite-rich host rock. Minor mineralization is present in a quartz vein stockwork on the edges of the syenitic complex.

A genetic model is proposed, wherein alkaline-oxidized magma, which favors sulfur and gold solubility and transport, migrates through the crust via major and subsidiary faults. The presence of miaroles, transolvus, and low-temperature crystallization conditions confirms the shallow emplacement of the magma. The high fluorine content of the magma, which lowers both viscosity and solidus temperature, favored the shallow emplacement of the magma and permitted the development of a long-lived magmatic-hydrothermal system. Oxygen and hydrogen isotopes, miaroles filling, and mineralized zone paragenesis confirm that oxidized hydrothermal fluids were exsolved from the magma. The planar geometry of the metasomatized ore zones indicates that hydrothermal fluid circulation and metasomatism reactions occurred preferentially in high permeability pathways, such as preexisting faults in the host rock. The redox contrast between the oxidized magmatic-hydrothermal fluid and the intermediate volcanic host rock caused sulfide precipitation and gold deposition. This genetic model is applied to the Abitibi subprovince and other Archean cratons.
\end{abstract}

\section{Introduction}

Archean greenstone belts host a wide range of gold deposits, including those that are late orogenic and intrusion related (Groves et al., 2003). Intrusion-related deposits have been recognized for more than 40 years (e.g., Franklin and Thorpe, 1982; Hattori, 1987; Sillitoe, 1991) and have since increased in economic importance. The largest producing gold deposits mined in Canada and in Australia since 2012-the Canadian Malartic in the Abitibi subprovince, and Boddington in the Yilgarn craton-are both associated with late-Archean intrusive rocks, from subvolcanic calc-alkaline tonalite-trondhjemitegranodiorite (TTG) to late syntectonic monzonite-syenite, belonging to the sanukitoids clan (Hattori, 1987; McCuaig et al., 2001; Robert, 2001; Galley, 2003; Duuring et al., 2007; Jébrak, 2011; Helt et al., 2014; De Souza et al., 2015; Jébrak and Fayol, 2015). However, they were not always identified as such because of their close spatial relationship to faults, epigenetic structurally hosted lode gold deposits (Kerrich, 1993), or orogenic gold deposits (Groves et al., 1998). The latter may overprint preexisting intrusion-related deposits (e.g., Canadian Malartic: Helt et al., 2014; De Souza et al., 2015; and Beattie: Bigot and Jébrak, 2015), making early intrusionrelated mineralization difficult to recognize.

In the Abitibi subprovince, several gold deposits (e.g., Beattie, Douay, Canadian Arrow) define a group of hydrothermal systems centered on late-Archean alkaline intrusions in the vicinity of late clastic sedimentary basins along major structural fault zones (Robert, 2001; Table 1). Based on the geochemistry of the intrusions, mineralization setting, and magnetic signature, these deposits can be divided into two groups, which are exemplified by the Beattie (Quebec) and the Canadian Arrow

† Corresponding author : e-mail, noemiefayol@gmail.com
(Ontario) deposits (Fayol et al., 2016). The Beattie syenite has a high ferromagnesian content, with abundant magnetite and a slightly fractionated rare earth element (REE) pattern. Gold is associated with disseminated pyrite within the intrusion and concentrated in late shear zones (Bigot and Jébrak, 2015). The Canadian Arrow intrusion has a lower ferromagnesian content, displays a low magnetic signature on regional surveys, and reveals a more highly differentiated magmatic process. The mineralization is concentrated along hematized discontinuities at the interface between the pluton and mafic volcanic host rocks. Although metasomatized ore zones are planar and sit on preexisting faults, gold is mainly associated with pyrite in K-Na-hematite-rich replacement zones, rather than in quartz veins characteristic of orogenic gold deposits (Lavigne, 2011).

In order to improve understanding of the genesis of such intrusion-related gold deposits, several parameters must be better constrained. First, the petrological, geological, and P-T characteristics of the intrusion need to be analyzed in order to identify key parameters leading to the development of an efficient hydrothermal system that allows gold deposition. Then, the timing of gold precipitation with regard to magmatic events has to be analyzed, and, finally, if the link between magmatism and gold is established, the chemical characteristics of the magmas and their role in gold transportation must be deciphered.

This paper provides a description of the geology and metallogeny of the Lac Bachelor deposit, which presents numerous characteristics of typical pluton-associated mineralization. The deposit is located in the northeastern part of the Abitibi subprovince, near the intersection between a major and unusual northeast-southwest structure, the Wedding-Lamarck deformation corridor and the east-west Opawica-Guercheville 


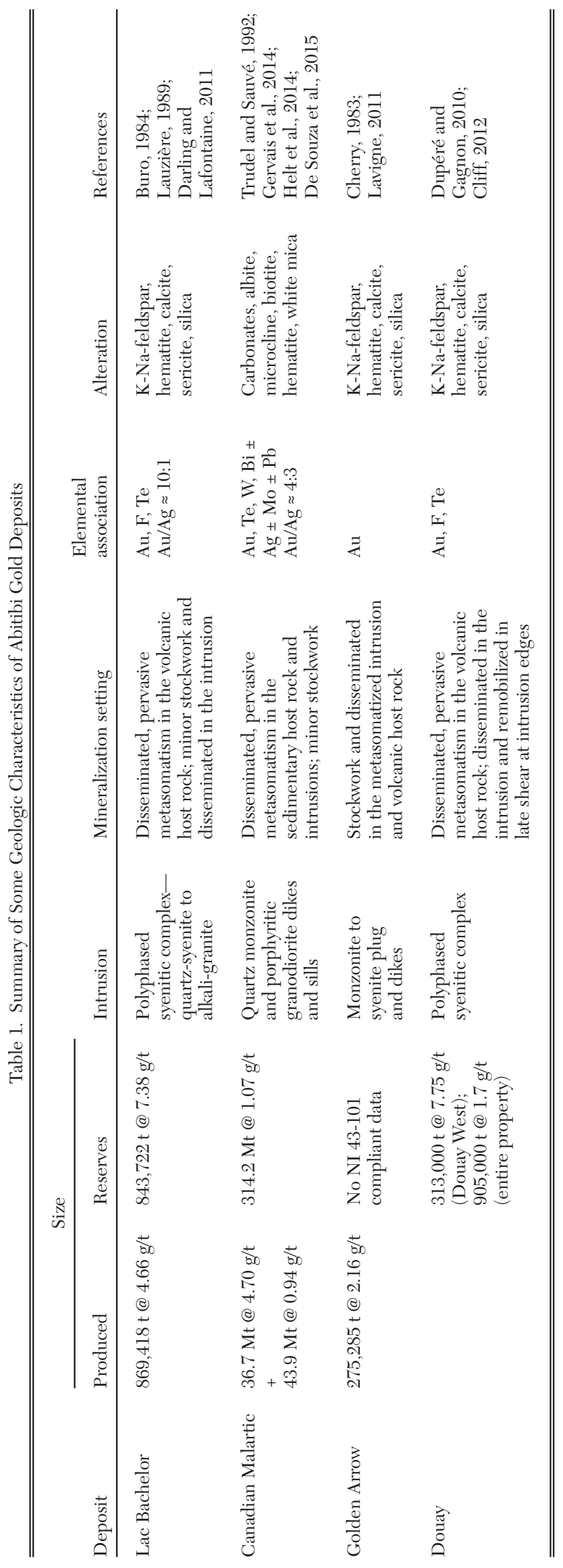

fault (Graham, 1957; Buro, 1984; Lauzière, 1989), which is also host to the Lac Shortt deposit (Fig. 1; Morasse, 1988; Prud'homme, 1990; Brisson, 1998; Nadeau et al., 2014). The deposit was reopened in 2011 by Metanor Resources Inc. after a successful exploration campaign that evaluated the Lac Bachelor gold resources at 6,558 $\mathrm{kg}(210,857 \mathrm{oz})$. The first ingot was produced in 2012, and the mine is currently in production to a depth of $696 \mathrm{~m}$. Its new underground access allowed the authors to precisely study the relationships between the mineralized zones and the intrusion, using petrography, geochemistry, and stable isotope analysis of quartz veins.

\section{Geologic Setting}

The Lac Bachelor gold deposit is located in the CaopatinaDesmaraisville segment of the Abitibi subprovince, near Desmaraisville, Québec (Fig. 1). The Archean volcanic stratigraphy consists of the Obatogamau Formation and the Wachigabau Member (Sharma et al., 1987). The 1- to 3-kmthick Obatogamau Formation comprises massive, pillowed, and brecciated basalts, with feldspar phenocrysts to megacrysts (Midra, 1989; Daigneault et al., 1990). The Wachigabau Member is less than $1 \mathrm{~km}$ thick, and consists of intermediate to felsic flows and pyroclastic rocks within the Obatogamau Formation (Sharma et al., 1987). At Desmaraisville, owing to the paucity of outcrops, the stratigraphy is poorly known. However, the geologic environment is constrained by observations at the Coniagas volcanogenic massive sulfide (VMS) deposit (Doucet et al., 1994, 1998), $3 \mathrm{~km}$ east of the Lac Bachelor deposit. This Zn-Pb-Ag VMS deposit produced 718,465 tonnes (t), grading $10.77 \% \mathrm{Zn}, 1 \% \mathrm{~Pb}, 0.05 \% \mathrm{Cu}$, and $183 \mathrm{~g} / \mathrm{t} \mathrm{Ag}$ (Allard et al., 1972; Doucet et al., 1998). It is hosted by a 280 -m-thick volcaniclastic sequence composed of massive, brecciated, and pillowed basaltic to andesitic flows and massive, stratified, and bedded lapilli tuffs. These units strike northeast and are steeply dipping and overturned. The main sulfide lens is a well-laminated sulfide ore zone, parallel to the regional bedding. It is interpreted to be the result of two explosive-effusive volcanic cycles in a submarine environment, with a volcanic center proximal to the Coniagas deposit ( 2730 Ma; Doucet et al., 1994, 1998).

The Lac Bachelor gold deposit is located near two small sedimentary basins (Doucet et al., 1995; Fayol et al., 2012) that are filled by Lac Bachelor and Auger sediments to the north and south, respectively (Fig. 1). These formations are composed of polygenic conglomerate, graywacke, siltstone, turbidite, and tuffs (Graham, 1957; Sharma and Lauzière, 1983; Doucet, 1993). Their stratigraphic position is uncertain, but they have been considered to be equivalent to the Haüy Formation in the Chapais area (Goutier and Melançon, 2010). The Haüy Formation is dated at $2692 \pm 3 \mathrm{Ma}$ (David et al., 2007) and is considered to be the Timiskaming sediment equivalent in northern Abitibi, despite being approximately 20 m.y. older than in the southern Abitibi (Thurston et al., 2008; Goutier and Melançon, 2010; Leclerc et al., 2011, 2012). Due to the polygenic composition of the Lac Bachelor conglomerates, both Lac Bachelor and Auger sedimentary rocks are considered to fill late-orogenic successor "Timiskaming-like" basins in the same ways that east-west detritic basins mark the major Cadillac-Larder Lake and Porcupine-Destor fault zones. 

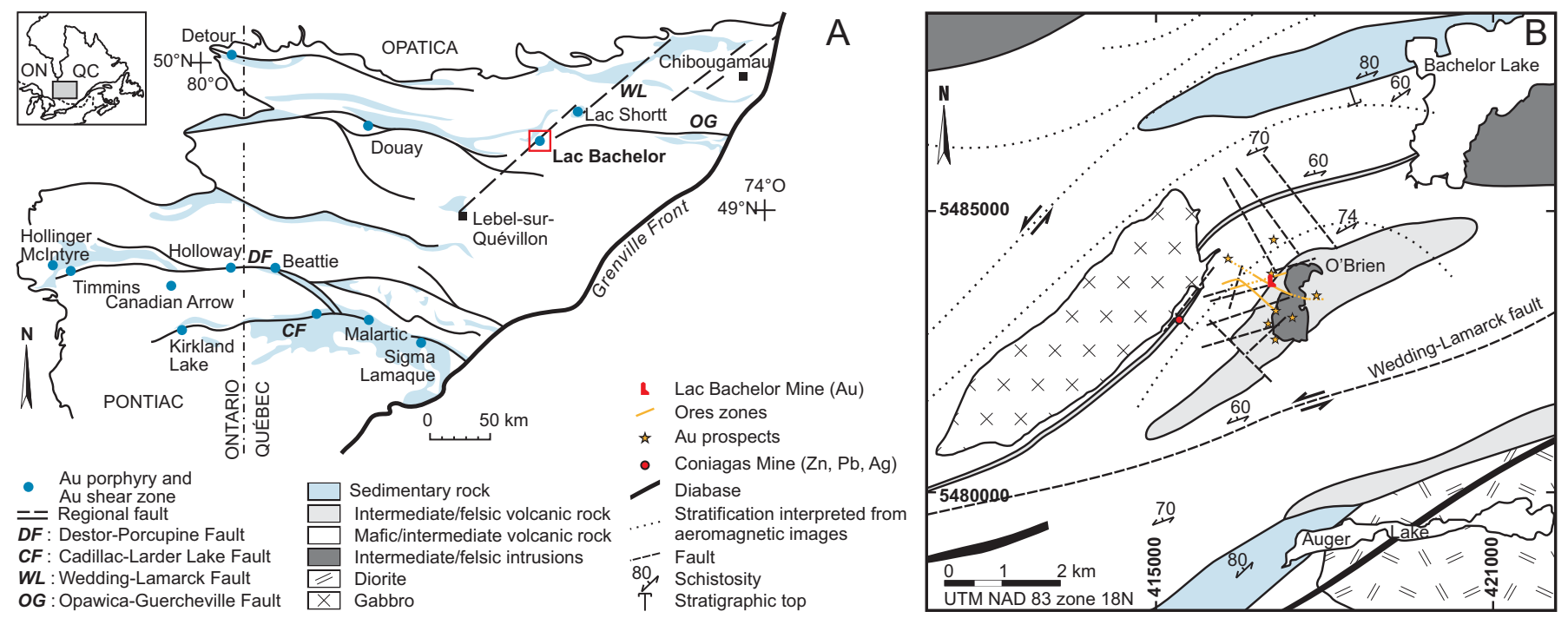

Fig. 1. A) Simplified geologic map of the Abitibi subprovince showing sedimentary basins, faults, and porphyry and shear zone-related gold deposits; inset shows the location of the Abitibi subprovince (modified from Jébrak and Marcoux, 2015). B) Geologic map of the Lac Bachelor mine area (modified from Doucet et al., 1994, 1998). The O'Brien quartz-syenite is intrusive into intermediate volcanic rocks. Two "Timiskaming-type" sedimentary rock formations are present to the north and south of the intrusion. The ore zones are located on the western side of the intrusion.

The felsic intrusions of the Abitibi subprovince have been categorized into three main groups depending of their relation to volcanism and tectonism: (1) ca. 2730-2700 Ma synvolcanic TTG intrusions; (2) ca. 2700-2692 Ma syntectonic granodiorite, rare tonalite, and monzodiorite plutons; and (3) ca. 2690-2670 Ma late-tectonic intrusions (Chown et al., 1992, 2002). These late- to posttectonic stocks have a monzonite to syenite composition and are often associated with lamprophyres and locally with carbonatites (e.g., Lac Shortt, Nadeau et al., 2014). The Lac Bachelor gold deposit is located at the edges of the late- to posttectonic O'Brien syenite stock complex (Graham, 1957; Buro, 1984; Morasse, 1988; Lauzière, 1989; Prud'homme, 1990; Brisson, 1998; Fayol et al., 2013; Nadeau et al., 2014) that intrudes the andesites and volcaniclastic rocks of the Obatogamau Formation.

The NE-trending Wedding-Lamarck deformation corridor extends over at least $150 \mathrm{~km}$, from the Abitibi-Opatica boundary to Lebel-sur-Quévillon (Fig. 1). This deformation zone, initially defined as the "Opawica fault" (Sharma and Lacoste, 1981), was later described as the Lamarck fault: a late brittle structure with an apparent sinistral movement (Charbonneau et al., 1983; Daigneault, 1996). However, recent studies based on geophysical data suggest a 25 -km-wide ductile deformation corridor overprinted by a late sinistral fault (Faure, 2011; Fayol et al., 2012; Harris and Bédard, 2014). The Bouguer gravity anomaly shows a high-density contrast between the west and east sides of the corridor. This suggests that the Wedding-Lamarck deformation corridor is a deep crustal structure that separates denser, more mafic crust to the west from a less dense block to the east (Fayol et al., 2012; Harris and Bédard, 2014). It is now interpreted as an early N-S crustal structure, the "proto-Wedding-Lamarck," which was cut by E-W-oriented regional shear zones with an apparent dextral offset (Fayol, 2016). Due to dextral displacement along these shear zones, the previously N-S-oriented crustal margin displayed a "stairlike" shape. During later N-S compression, these stairlike shaped crustal heterogeneities localized the deformation and induced the NE-SW orientation of the actual Wedding-Lamarck deformation corridor. The last recorded movements indicate that the Wedding-Lamarck deformation corridor is a brittle-ductile sinistral shear zone (Faure, 2011; Fayol et al., 2012; Harris and Bédard, 2014). In this evolution model, the Opawica-Guercheville deformation zone may be an early ductile dextral shear zone that was reactivated under brittle-ductile conditions. Vertical movement of this steeply dipping shear zone was also observed in the field (Daigneault, 1996; Brisson, 1998).

\section{Sampling and Analytical Techniques}

Sampling and observation of the intrusive rocks, mineralization, veins, and alteration zones were mainly done underground, at levels 6 to 14 on the western margin of the O'Brien stock. Whole-rock lithogeochemical analyses were completed at Acme Analytical Laboratories in Vancouver, Canada. Samples were crushed, fused with lithium meta/tetraborate, and dissolved in nitric acid. More precise analyses were performed for $\mathrm{Au}$ and other volatile elements with aqua regia digestion. Major and trace elements were then determined by inductively coupled plasma-mass spectrometry (ICP-MS) and ICPoptical emission spectroscopy (OES). F concentrations were obtained by $\mathrm{NaOH}$ fusion, water digestion, and acidification, followed by the potentiometric method.

Petrographic observations were done with a Leica DMLP transmitted-reflected light-polarizing microscope. Detailed characterizations were performed at the UQAM scanning electron microscopy (SEM) laboratory using a Hitachi TM3000 (LV-SEM) with energy-dispersive X-ray spectrometry (EDS) and backscattered electron (BSE) imaging.

Hydrogen and oxygen isotope concentrations were measured for 22 samples representing six types of quartz veins. 
Analyses were processed on bulk fluid samples at the Queen's University Facility for Isotope Research (Canada). Oxygen isotopes were measured using a Thermo-Finnigan DeltaPlusXP continuous-flow isotope ratio mass spectrometer (CF-IRMS) on quartz. Hydrogen isotopes were measured on fluid inclusions in quartz using a Thermo-Finnigan thermo-combustion elemental analyzer (TC/EA) coupled to a Thermo-Finnigan DeltaPlus XP CF-IRMS. Both $\delta \mathrm{D}$ and $\delta^{18} \mathrm{O}$ are given in per mil, relative to Vienna-standard mean ocean water (V-SMOW), with $3 \%$ and $0.1 \%$ precisions, respectively.

\section{Deposit Geology}

Gold was first discovered on the eastern margin of the O'Brien stock in autumn 1946 by O'Brien Gold Mines Ltd. Following this discovery, exploration was conducted both at the surface and underground until 1982, when Bachelor Lake Gold Mines Inc. reached commercial production (Darling and Lafontaine, 2011).

The Lac Bachelor mine has had past production of $869,418 \mathrm{t}$ at $4.66 \mathrm{~g} / \mathrm{t}$ grade, equivalent to $4,054 \mathrm{~kg}$ (130,338 oz) of gold extracted between 1982 and 1989. In the last resource estimate, prior to current production, the total proven and probable resources for the Lac Bachelor deposit and its immediate extension zones were estimated at $843,722 \mathrm{t}$ at $7.38 \mathrm{~g} / \mathrm{t}$, for a total of $6,226 \mathrm{~kg}(200,177 \mathrm{oz}$, NI 43-101; Darling and Lafontaine, 2011).

The Lac Bachelor deposit is located at the western limit of the O'Brien syenitic complex; however, the initial discovery was at the eastern side of the intrusion. Known mineralization is mainly hosted in three almost planar replacement zones within the andesites and volcaniclastic rocks that are intruded by the O'Brien stock. Minor mineralization is also found within the intrusion itself, both disseminated and in stockwork.

\section{Host rock}

Andesites and volcaniclastic rocks of the Obatogamau Formation consist of massive, brecciated, and pillowed basaltic to andesitic flows and massive, stratified, and bedded lapilli tuffs (Graham, 1957; Doucet et al., 1994). This volcanic assemblage trends SSW to SW and dips $\sim 70^{\circ}$ to $80^{\circ} \mathrm{NW}$. These volcanic rocks are aphanitic to fine grained; locally, centimetric feldspar phenocrysts or amygdules are present.

Volcanic lavas are characterized by up to $70 \%$ euhedral Mg-chlorite, sericite, actinolite, epidote (1-5\%), and a fine quartz-feldspar matrix. Volcaniclastic rocks present the same mineral assemblage; however, the proportion of mafic minerals is less, and there are more felsic minerals and fragments. The above-mentioned mineral assemblage is characteristic of lower greenschist metamorphism of intermediate volcanic rocks. Very fine magnetite with hematite edges and pyrite are present locally.

The use of immobile elements on the $\mathrm{Zr} / \mathrm{TiO}_{2}$ vs. Nb/Y diagram (Winchester and Floyd, 1977; Fig. 2) indicates that volcanic flows and volcaniclastic rocks have similar andesitic basalt to andesite composition. REEs normalized to primitive mantle profiles (Fig. 3) are almost flat, with slight fractionation and a negative Eu anomaly. This low fractionation is consistent with the andesitic and basaltic composition of a tholeiitic melt. The tholeiitic affinity of the volcanic rocks along with the presence of pillows and volcaniclastic rocks suggest a submarine environment with a proximal volcanic center with both effusive and explosive activity (Doucet et al., 1994).

Lamprophyre dikes ranging from a few centimeters to a meter in width cut host rock and mineralized zones. Proterozoic gabbro dikes as wide as $5 \mathrm{~m}$ and hundreds of meters long, striking NNE and dipping $30^{\circ} \mathrm{E}$, cut both host rock and mineralized zones (observed in the mine and Lauzière, 1989).

\section{O’Brien syenitic complex}

The O'Brien syenitic complex is a $0.6 \mathrm{~km}^{2}$ oval-shaped intrusion (Fig. 1). Oriented N-S, its maximum length is $1.3 \mathrm{~km}$ and its width is about 0.5 to $0.6 \mathrm{~km}$. The intrusion is not exposed at the surface, but is apparent on aeromagnetic images as a low magnetic zone surrounded by a 500 -m-wide, highly magnetic halo within the volcanic rocks (Fig. 4; Fayol et al., 2016). The

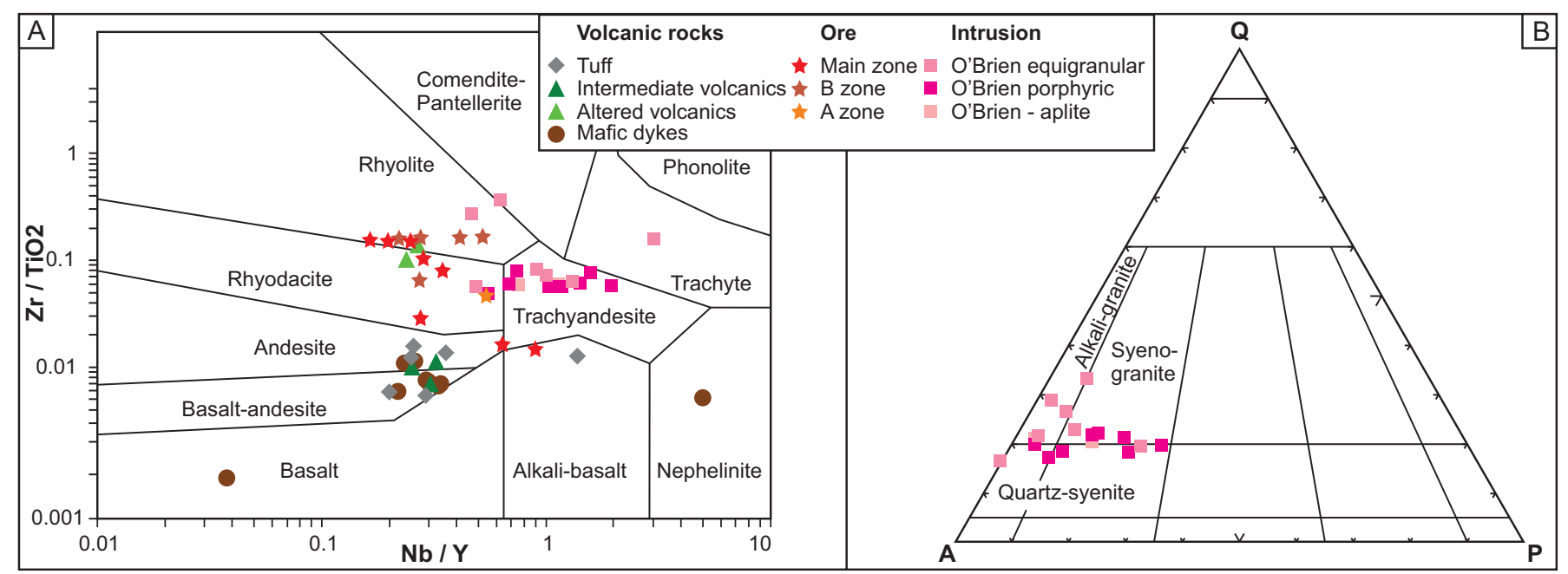

Fig. 2. A) $\mathrm{Zr} / \mathrm{TiO}_{2}$ vs. $\mathrm{Nb} / \mathrm{Y}$ petrological classification (Winchester and Floyd, 1977). The host rock has a basaltic to andesitic composition. B) Streckeisen plot of the three facies of the O'Brien stock; the compositions range from quartz-syenite to alkali-granite. 


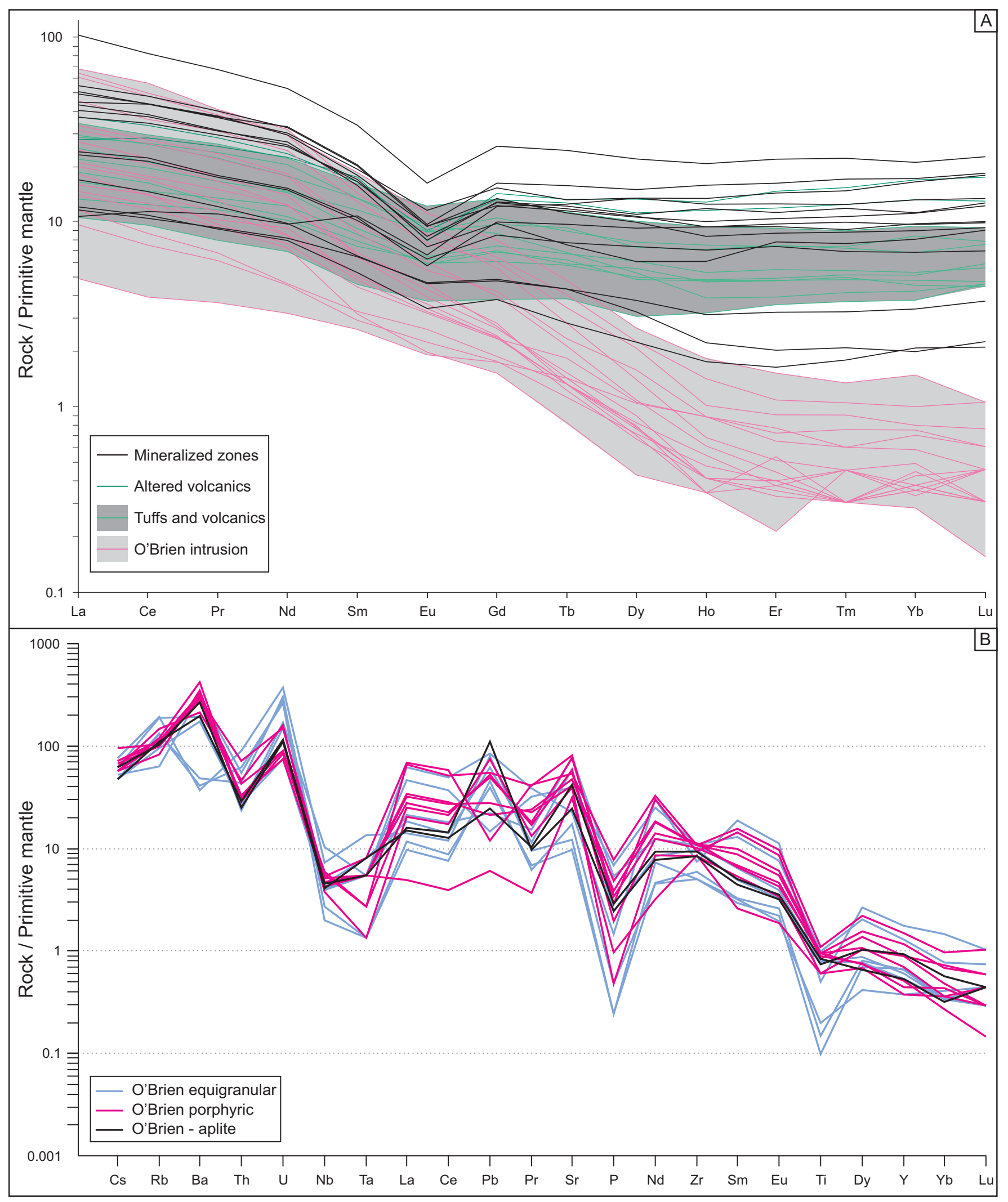

Fig. 3. A) REE profiles normalized to primitive mantle (McDonough and Sun, 1995). Host rock has a typical, almost flat, tholeiitic profile. The O'Brien stock has a fractionated profile with no europium anomaly. Mineralized zone profiles show a slight REE enrichment compared to the host rock, but have the same shape; B) spider diagram of the equigranular, porphyritic, and aplitic facies of the O'Brien stock; profiles with $\mathrm{Nb}, \mathrm{Ta}$, and $\mathrm{Ti}$ anomalies are typical of an arc setting, although this interpretation may not be unique (Bédard et al., 2013). 

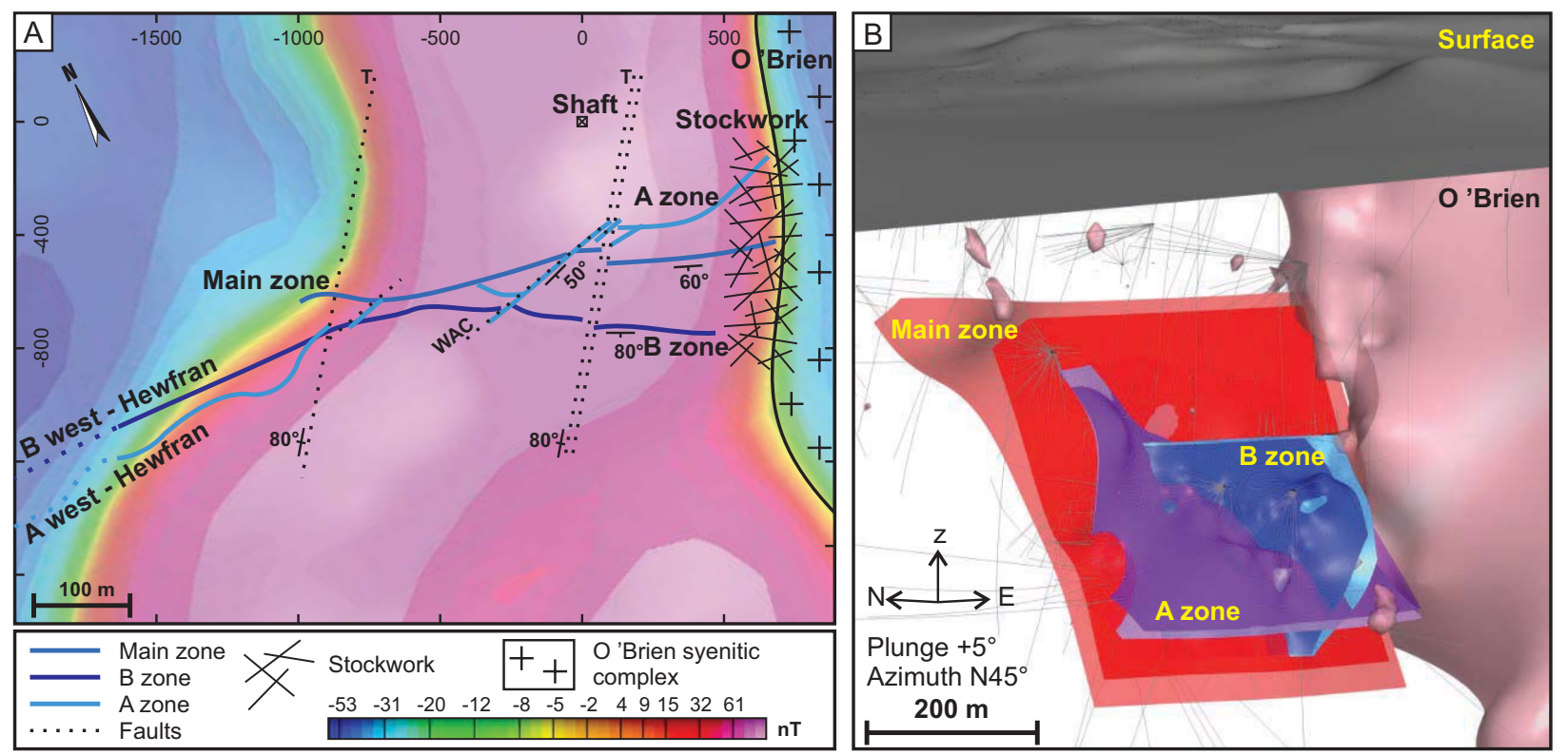

Fig. 4. A) Schematic plan view of the Lac Bachelor mineralized zone (from level 11 geometry) and magnetic halo (aeromagnetic residual field). The O’Brien selvage hosts a well-developed stockwork. Main and B zones are oriented $\mathrm{N} 100^{\circ}$ to $110^{\circ}$, and dip $60^{\circ}$ to $80^{\circ} \mathrm{S}$; they are cut by the A zone, which follows the Waconichi fault system. Transversal (T) NNE-oriented late faults cut all ore zones. B) 3D view of the Lac Bachelor mineralized zones and O'Brien syenite modelled from the drill hole database using Leapfrog mining software.

only access available is at the western margin of the intrusion, in a few galleries of the Lac Bachelor mine. Previous studies were able to access several historical drill holes that are no longer available (Graham, 1957; Buro, 1984; Lauzière, 1989). At level 6 (corresponding to $270 \mathrm{~m}$ in depth), the O'Brien stock contact is exposed for over $150 \mathrm{~m}$ from west to east. The contact is exposed sporadically from 350 to $620 \mathrm{~m}$ at depth in four levels. In previous studies, the main part of the intrusion was described as an equigranular to porphyritic albite-granite (Graham, 1957) or an equigranular to porphyritic granodiorite to granite, mainly composed of plagioclase, K-feldspar, quartz, and hornblende in its central part, with later aplitic and porphyritic dikes (Buro, 1984; Lauzière, 1989).

Access to the O'Brien stock is currently limited to its western margin. Three main facies can be observed: (1) porphyritic, (2) equigranular, and (3) aplitic. The porphyritic facies is the most abundant. The equigranular facies represents the oldest phase of the intrusion. Both porphyritic and equigranular facies are cut by centimeter- to decimeter-wide aplite dikes, oriented NNE and NNW, and steeply dipping to the west (Fig. 5). The spatial distribution of these facies remains poorly known due to the paucity of exposure. Detailed mineralogy is given in Table 2. Depending on the intensity of the hematite dust alteration, the color of the intrusion varies from pale to intense pink. Locally, intense carbonate alteration produces a beige color.

\section{Petrography}

The porphyritic facies (Fig. 5a) corresponds to a quartzsyenite with albite and K-feldspar phenocrysts in a finer quartz-feldspar matrix. Albite and K-feldspar are mostly euhedral with Carlsbad and polysynthetic twins. Perthite is very common. Feldspars represent 75 to $95 \%$ of the rock.
Quartz is always anhedral, with undulose extinction. The finest minerals show sutured grain boundaries indicative of recrystallization. Quartz represents 5 to $20 \%$ of the rock. The mafic minerals $(<3 \%)$ are anhedral $\mathrm{Fe}-\mathrm{Mg}$ chlorite and hydrothermal biotite. They may replace the hornblende observed by Lauzière (1989) in the center of the intrusion. Accessory minerals-purple fluorite, subhedral fluorapatite (ca. 4\% F, SEM-EDS measurement), barite, euhedral zircon, titanite, and rutile-represent less than 1\% each (Fig. 5h). Rare metallic minerals are disseminated. Pyrite has a subhedral to euhedral cubic shape. Chalcopyrite is rare and subhedral. Magnetite and hematite represent up to $1 \%$ of the rock. Magnetite is either skeletal or cubic, with hematite edges. Rare visible gold is present as isolated grains of less than 500 $\mu \mathrm{m}$. Sericite is present in the porphyritic facies as very fine needles in feldspars and, rarely, as coarser intergranular flakes in the matrix, and thus represents a strong sericitic alteration (Fig. 5d-f). Slight carbonate alteration occurred as rare anhedral carbonate, mainly dolomite and, more rarely, calcite crystals. Some centimeter-size miaroles (Fig. 5g) are indicative of a shallow emplacement. They encompass fluorite, fluorapatite, barite, calcite, and muscovite. In the O'Brien porphyritic facies, zircons are homogeneous. According to Pupin (1980), zircon shape is dependent on both the temperature ( $\mathrm{T}$ index) and agpaicity (A index) of the crystallizing magma. Their elongated and prismatic shape with bevelled pyramidal edges (Fig. 5i) corresponds to a G type (Pupin, 1980) with a T index of 300 and an A index equal to 700, the former indicating a temperature of $650^{\circ} \mathrm{C}$, and the latter being characteristic of alkaline intrusions.

The equigranular, alkali-granite facies (Fig. 5b) is characterized by equigranular albite, K-feldspar, and quartz. Albite and K-feldspar are mostly euhedral, with Carlsbad 

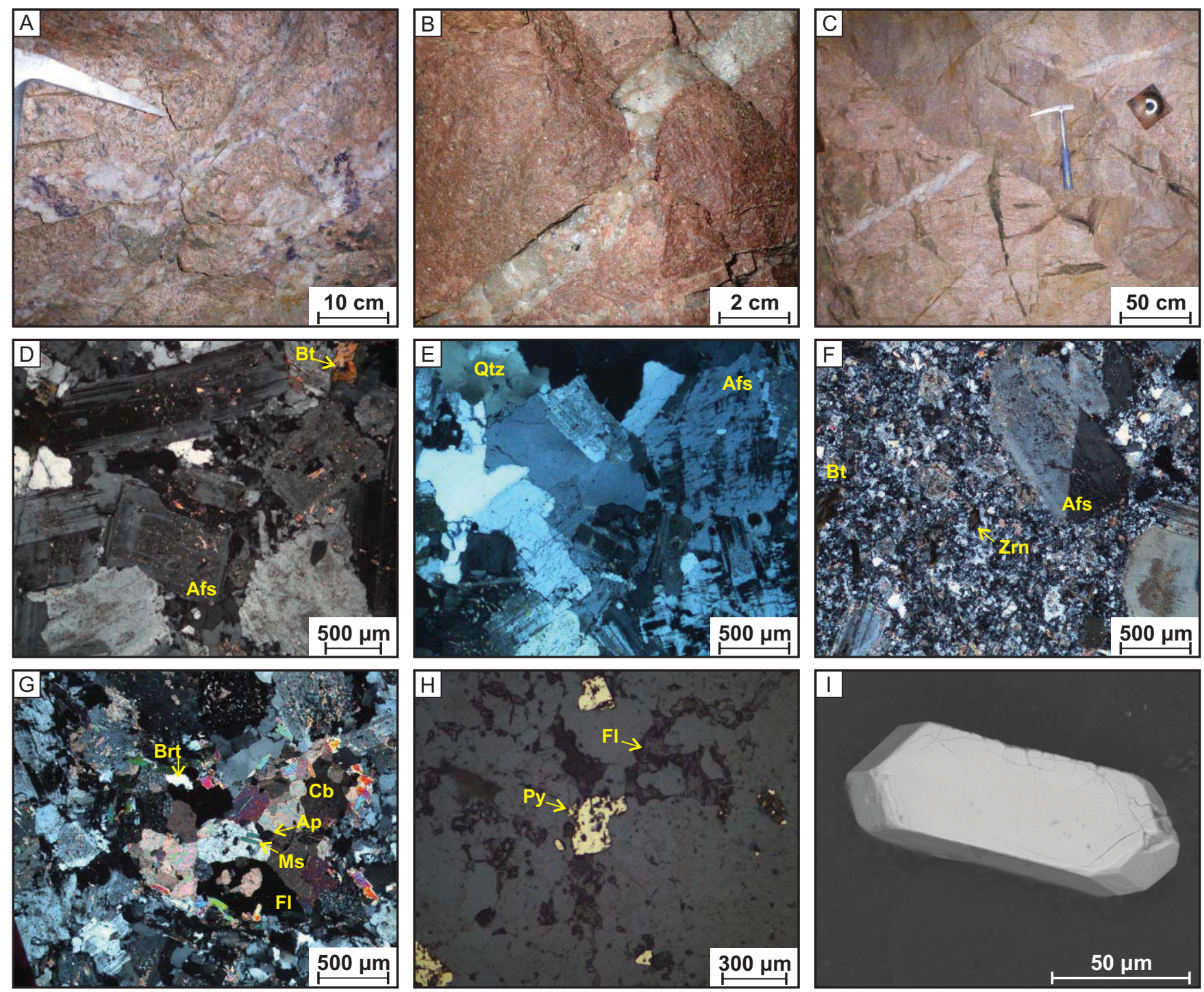

Fig. 5. O'Brien stock: A) porphyritic facies with fluorite; A) equigranular facies; C) aplite cutting through the porphyritic facies and a quartz-fluorite vein; D-F) O'Brien stock samples in thin sections showing altered and zoned alkali-feldspars, hydrothermal biotite, zircon, carbonates, fluorite, and pyrite; G) miarolitic cavity filled with fluorite, apatite, carbonate, barite, and muscovite; H) pyrite and fluorite; and I) SEM images of a "G-shape" zircon from the intrusion. Afs = alkali-feldspars, $\mathrm{Ap}=$ apatite, $\mathrm{Brt}=$ barite, $\mathrm{Bt}=$ biotite, $\mathrm{Cb}=$ carbonate, $\mathrm{Fl}=$ fluorite, $\mathrm{Ms}=$ muscovite, $\mathrm{Py}=$ pyrite, $\mathrm{Zrn}=$ zircon .

and polysynthetic twins. Feldspars represent $65 \%$ of the rock. Quartz (35\%) is always anhedral, with undulose extinction. Sericite is present in the equigranular facies as very fine needles in feldspars and, rarely, coarser intergranular flakes, and thus represents strong sericitic alteration. Accessory minerals - purple fluorite, euhedral zircon, titanite, and rutile-represent less than $1 \%$ each. Rare metallic minerals are disseminated. Pyrite has a subhedral to euhedral cubic shape and is porous. Chalcopyrite is rare and subhedral. Very rare and fine galena occurs. Magnetite-hematite association is either skeletal or in inclusion in the pyrite. Slight carbonate alteration is indicated by rare anhedral carbonate crystals.

Aplites (Fig. 5c) are characterized by albite and K-feldspar phenocrysts $(30 \%)$ in a finer quartz-feldspar matrix. They have a quartz-syenite to syenogranite composition. Albite and $\mathrm{K}$-feldspar are mostly euhedral with Carlsbad and polysynthetic twins. Perthite is very common. All together, feldspars represent 70 to $80 \%$ of the rock. Quartz is always anhedral with undulose extinction. The finest minerals show sutured grain boundaries indicative of recrystallization. Quartz represents 10 to $20 \%$ of the rock. Very rare oval-shaped quartz grains are present. Mafic minerals $(<2 \%)$ consist of anhedral $\mathrm{Fe}-\mathrm{Mg}$ chlorite and hydrothermal biotite. Accessory minerals - purple fluorite, subhedral fluorapatite, barite, euhedral zircon, titanite, and rutile-represent less than 1\% each. Rare metallic minerals are disseminated. Pyrite has a subhedral to euhedral cubic shape. Chalcopyrite is rare and subhedral. The magnetite-hematite association represents up to $2 \%$ of the rock. Magnetite is either skeletal or cubic with hematite edges. Sericite (1-2\%) is present in aplite as very fine needles in feldspars and, rarely, as coarser intergranular flakes in the matrix, and thus is evidence of strong sericitic alteration. Slight carbonate alteration occurred, evidenced by rare anhedral calcite crystals. 
Table 2. Detailed Mineralogy of the Three Facies of the O'Brien Stock

\begin{tabular}{|c|c|c|c|c|c|c|c|c|c|}
\hline & \multicolumn{3}{|c|}{ Porphyritic quartz-syenite } & \multicolumn{3}{|c|}{ Aplite } & \multicolumn{3}{|c|}{ Equigranular alkali-granite } \\
\hline & Description & Size $(\mu \mathrm{m})$ & $\%$ & Description & Size $(\mu \mathrm{m})$ & $\%$ & Description & Size $(\mu \mathrm{m})$ & $\%$ \\
\hline Afs & $\begin{array}{l}\text { Euhedral-porphyritic: } \\
\text { perthite, polysynthetic, } \\
\text { Carlsbad, Mc }\end{array}$ & $500-7,500$ & $75-95$ & $\begin{array}{l}\text { Euhedral-zoned; } \\
\text { porphyritic: perthite, } \\
\text { polysynthetic, } \\
\text { Carlsbad, Mc }\end{array}$ & $400-5,000$ & 30 & $\begin{array}{l}\text { Euhedral: } \\
\text { polysynthetic, } \\
\text { Carlsbad, Mc }\end{array}$ & $400-1,000$ & 65 \\
\hline Qtz & Anhedral & $200-1,500$ & $2-10$ & Anhedral & $25-125$ & $1-5$ & Anhedral & $400-1,000$ & 35 \\
\hline $\begin{array}{l}\text { Qtz-Afs } \\
\text { Matrix }\end{array}$ & $\begin{array}{l}\text { Anhedral Qtz: sutured } \\
\text { grain boundaries }\end{array}$ & $25-50$ & $5-10$ & $\begin{array}{l}\text { Subhedral Afs; } \\
\text { anhedral Qtz: sutured } \\
\text { grain boundaries }\end{array}$ & $25-75$ & $\begin{array}{l}\text { Afs40-50 } \\
\text { Qtz10-20 }\end{array}$ & & & \\
\hline $\mathrm{Fl}$ & Anhedral & $100-750$ & $<1$ & Anhedral & & $<1$ & Anhedral to subhedral & $50-500$ & $<1$ \\
\hline Brt & Anhedral & $50-100$ & $<1$ & Anhedral & $10-20$ & $<1$ & & & \\
\hline Ap & Subhedral & $100-250$ & $<1$ & Subhedral & $50-125$ & $<1$ & & & \\
\hline Ser/Ms & $\begin{array}{l}\text { Needles in Afs, } \\
\text { rarely in the matrix }\end{array}$ & $\begin{array}{l}<25 \\
25-250\end{array}$ & $1-3$ & $\begin{array}{l}\text { Needles in Afs, } \\
\text { rarely in the matrix }\end{array}$ & $<25$ & $1-2$ & $\begin{array}{l}\text { Needles in Afs, } \\
\text { rarely in the matrix }\end{array}$ & $25-125$ & 1 \\
\hline $\mathrm{Bt}$ & Anhedral to subhedral & $125-500$ & $<2$ & Subhedral & $125-1,500$ & $<1$ & & & \\
\hline Fe-Mg-Chl & Anhedral to subhedral & $100-250$ & $<1$ & Subhedral & 125 & $<1$ & & & \\
\hline $\mathrm{Cb}$ & Anhedral & & $<1$ & & & & Intergranular, anhedral & $50-1250$ & 1 \\
\hline $\mathrm{Zr}$ & Euhedral & $25-125$ & $<1$ & Euhedral & $25-125$ & $<1$ & Euhedral & $50-125$ & $<1$ \\
\hline Ttn & Euhedral & $25-100$ & $<1$ & Euhedral & $25-250$ & $<1$ & Euhedral & $50-100$ & $<1$ \\
\hline Rt & Anhedral & $25-500$ & $<1$ & Anhedral & 50 & $<1$ & Anhedral & 10 & $<1$ \\
\hline Mag-Hem & $\begin{array}{l}\text { Skeletal or cubic } \\
\text { Mag-Hem }\end{array}$ & $\begin{array}{l}50-250 \text { to } \\
500-1000\end{array}$ & $<1$ & $\begin{array}{l}\text { Skeletal or cubic } \\
\text { Mag-Hem }\end{array}$ & 125 & $<2$ & $\begin{array}{l}\text { Skeletal and } \\
\text { inclusions in Py }\end{array}$ & $25-125$ & $<1$ \\
\hline Py & Subhedral, cubic & $50-150$ & $<1$ & Subhedral, cubic & $25-125$ & $<1$ & Subhedral, cubic, porous & $25-300$ & $<1$ \\
\hline Сcp & Subhedral & $250-500$ & $<1$ & & & & Subhedral & $250-500$ & $<1$ \\
\hline $\mathrm{Gn}$ & & & & Anhedral & $5-10$ & $<1$ & Anhedral & 5-10 & $<1$ \\
\hline $\begin{array}{l}\text { Gold } \\
\mathrm{Au}-\mathrm{Ag}-\mathrm{Te}\end{array}$ & Disseminated & $<500$ & $<1$ & & & & & & \\
\hline
\end{tabular}

Note: Porphyritic and aplite facies have the same composition; the equigranular facies contains more quartz

Abbreviations: Afs = alkali-feldspar, Ap = apatite, Brt = barite, $\mathrm{Bt}=$ biotite, $\mathrm{Ccp}=$ chalcopyrite, $\mathrm{Chl}=\mathrm{chlorite}, \mathrm{Fl}=\mathrm{fluorite}, \mathrm{Gn}=\mathrm{galena}, \mathrm{Hem}=\mathrm{hematite}$, Mag = magnetite, $\mathrm{Mc}=$ microcline, $\mathrm{Ms}=$ muscovite, $\mathrm{Py}=$ pyrite, $\mathrm{Qtz}=$ quartz, $\mathrm{Rt}=$ rutile, Ser $=$ sericite, Subh $=$ subhedral, Ttn $=$ titanite, $\mathrm{Zrn}=\mathrm{zircon}$

All three facies were affected by hydrothermal alteration, especially sericitic alteration of feldspars and martitization of magnetite. Undulose extinction and sutured grain boundaries of quartz indicate that the O'Brien syenitic complex underwent postsolidus strain that caused quartz annealing.

The western margin of the O'Brien stock consists of a swarm of apophyses and aplite dikes cutting through the volcanic rocks. Contacts are either intrusive or faulted, and volcanic rocks in the nearby area are strongly altered to hematite. Hematite-altered intrusive rocks of the O'Brien stock have a distinctive red color and a low magnetic susceptibility that is less than $1.10^{-3}$ SI (Fayol et al., 2016). The alkaline granitic magma has intruded the volcanic rocks under brittle-ductile conditions and has been emplaced by at least two pulses. This timing is confirmed by the relationship between intrusion phases and quartz veins.

\section{Geochemistry}

Alteration and the presence of veinlets in the O'Brien stock samples have to be considered when interpreting the geochemical analyses of the three O'Brien stock facies. Geochemistry based on major elements is strongly affected by the presence of small quartz veinlets in the samples. An overestimation of the $\mathrm{SiO}_{2}$ percent is a result, and thus a shifting of the data in diagram along a $\mathrm{SiO}_{2}$-based axis is predictable. Therefore, a multidiagram approach was used. First, the calculation of the CIPW norm followed by a Streckeisen plot (Fig. 2) clearly indicates that the O'Brien stock has a composition that ranges from quartz-syenite and syenogranite for the porphyritic and aplite facies to alkali-granite for the equigranular facies; this is consistent with petrographic observations. The use of immobile elements on the $\mathrm{Zr} / \mathrm{TiO}_{2}$ vs. $\mathrm{Nb} / \mathrm{Y}$ diagram (Winchester and Floyd, 1977; Fig. 2) confirmed the syenitic composition of the O'Brien stock. All O'Brien facies have high fluorine content. The mean of 12 samples is $\mathrm{F}=$ $1.659_{-1075}^{+180} \mathrm{ppm}$. The O'Brien stock has an alkali-calcic to alkaline affinity.

The REE diagram (Fig. 3a) shows that REE patterns are similar for all O'Brien samples, without distinction between the three facies. Fractionation between light REEs (LREEs) and heavy REEs (HREEs) is significant, spanning two orders of magnitude. There is no europium anomaly. The spider diagram normalized to primitive mantle (Fig. 3b) shows strong negative $\mathrm{Nb}, \mathrm{Ta}$, and Ti anomalies. The porphyritic and the aplitic facies of the O'Brien stock are rich in $\mathrm{Ba}(\mathrm{Ba}>1,000 \mathrm{ppm})$ and $\mathrm{Sr}$ (Sr $>400 \mathrm{ppm}$ ) (Table 3). The O'Brien stock displays most of the characteristics of the more evolved sanukitoids, sensu lato intrusions, as defined by Laurent et al. (2014). 


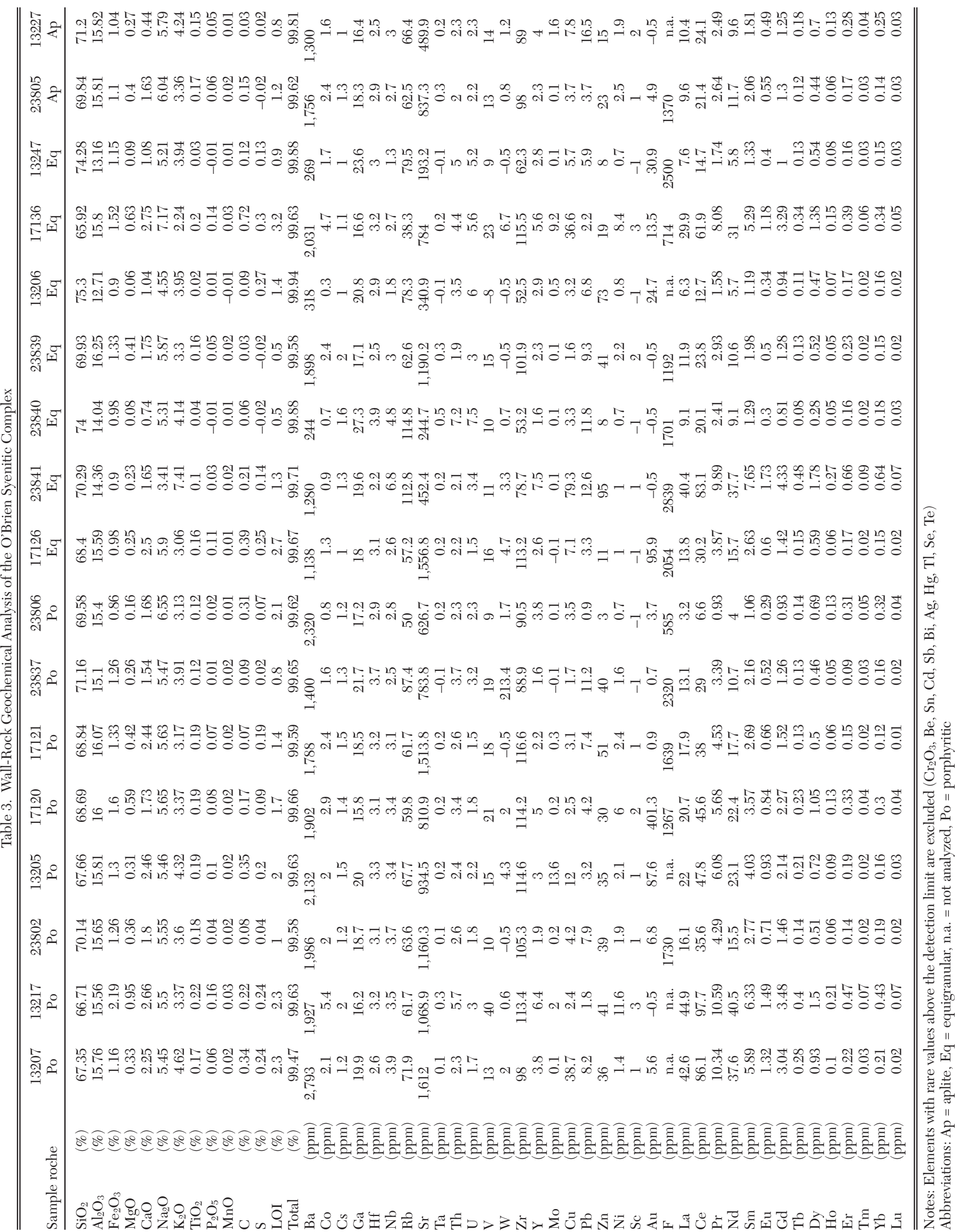




\section{Faults}

Three families of faults are observed in the Lac Bachelor mine:

1. The Waconichi (WAC) faults trend ENE, and are $70^{\circ} \mathrm{SE}$ dipping. They form decametric- to few meter-wide shear zones, and are sometimes mineralized (A zone); they are pre- to synmineralization. Lauzière (1989) divided the Waconichi fault family into two groups: the WAC (N 70 $\left.60^{\circ} \mathrm{SE}\right)$ and the WAC' $\left(\mathrm{N} 50^{\circ}-80^{\circ} \mathrm{SE}\right)$, but this division was not confirmed by our observations;

2. The Transversal (T) faults consistently strike NNE, are subvertical, and slickenside striation in a few instances indicates probable dextral movement along these faults;

3. The Transversal ( $\mathrm{T}^{\prime}$ ) faults consistently strike NW to $\mathrm{N}$, are subvertical, and slickenside striation in a few instances indicates sinistral movement along these faults.

$\mathrm{T}$ and $\mathrm{T}$ ' fault poles fit on a same large circle; the mean angle between $\mathrm{T}$ and $\mathrm{T}^{\prime}$ planes is $60^{\circ}$ (i.e., between ca. $40^{\circ}-$ $80^{\circ}$ ). These two families of faults therefore appear to be conjugate, and the implied maximum principal stress $\left(\sigma_{1}\right)$ is oriented ENE-WSW. They are very abundant, and cut mineralized zones. The width of "Transverse" faults varies from a centimeter to a few decimeters; a chlorite matrix is common. These faults record a brittle tectonic event occurring during late to postmineralization.

\section{Mineralization styles}

In the Lac Bachelor deposit, gold is associated with both zones of pervasive metasomatism and porphyry-style stockwork. The historical and present gold production comes primarily from Main, B, and A planar metasomatized ore zones in the volcanic host rocks at the western margin of the O'Brien stock. The porphyry-style stockwork mineralization makes only a minor contribution to the total gold production.

Planar metasomatized ore zones: Main, B, and A planar replacement zones extend from the western margin of the O'Brien stock for over $500 \mathrm{~m}$ in the volcanic host rocks (Fig. 4). These replacement zones are located within the highly magnetic aureole that surrounds the O'Brien stock.

The Main zone is almost planar, trending north $110^{\circ}$ and dipping $60^{\circ}$ south. This zone, mined from level 1 to 14,40 to $620 \mathrm{~m}$ deep, and over $500 \mathrm{~m}$ in length, is in contact with the western edge and dikes of the intrusion at almost all levels. The average thickness is $3 \mathrm{~m}$. The $\mathrm{B}$ zone is almost planar, trending north $115^{\circ}$ and dipping $80^{\circ}$ south. This zone is mined from level 11 to 14,470 to $620 \mathrm{~m}$ deep, and has over $200 \mathrm{~m}$ of lateral extension. The width is similar to that of the Main zone, about $3 \mathrm{~m}$. Main and B zones intersect at level 13; the exposure did not allow precise determination of the relative crosscutting relationship. The A mineralization trends north $70^{\circ}$ to $80^{\circ}$ and dips $50^{\circ}$ south; it corresponds to the Waconichi fault system. It is recognized and mined from level 4 to 14 (180-620 m); however, the grade is lower than in Main and $\mathrm{B}$ zones, with the best grades occurring at intersections with these zones.

Contacts between mineralized zones and the host rocks are sharp; the intensity of the hematite alteration (red ore) and gold grades decreases within less than a meter of the contact. Locally, brown breccia (breccia ore) and quartz veinlets extend within the host rocks over few meters. Main and B zones are cut by the Waconichi fault system that trends north $80^{\circ}$ and strikes $50^{\circ}$ to $60^{\circ} \mathrm{SE}$.

Mineralogy: Alteration assemblages appear similar in the Main and B zones; these zones are known to have the same $7.6 \mathrm{~g} / \mathrm{t}$ grade (Darling and Lafontaine, 2011). The main orebody is an intense red color and has an aphanitic to fine-grained matrix with disseminated pyrite (Fig. 6). Locally, the orebody is brown rather than red due to local carbonate alteration. The matrix is composed of very fine grains $(<10 \mu \mathrm{m})$ of quartz, and as much as 70 to $90 \% \mathrm{~K}$-feldspar and albite. Very rare albite and K-feldspar phenocrysts are present. The remaining 10 to $30 \%$ consists of dolomite, fluorapatite, Mg-chlorite, sericite, magnetite, hematite, rutile, and very rare tourmaline (uvite, SEM-EDS determination), zircon, and REE minerals (Ce-FLREE silico-calcic and Ce-phosphate; SEM-EDS). Locally, the carbonate alteration can reach $30 \%$.

A minor volume of ore appears in brecciated, beige-colored rocks. This "breccia-type ore" occurs in contact with quartzsyenite dikes, and at some contact zones between the red-type ore and the host rocks. The carbonate alteration, chiefly dolomite, is more intense than in the red-type ore and occurs as veinlets; otherwise, the mineralogy is similar.

Sulfides include pyrite, with very rare chalcopyrite and pyrrhotite. Three pyrite types are identified (Fig. 6, Table 4) based on grain size, shape, and porosity:

1. P1: Fine to coarse pyrite, $60 \mu \mathrm{m}$ to $2 \mathrm{~mm}$, highly porous, and euhedral. These display a wide range of inclusions: (1) subhedral to euhedral minerals: K-feldspar, albite, quartz, carbonate, Fe-Mg chlorite, fluorapatite, fluorite, barite,

Table 4. Pyrite Classification (SEM-EDX observations and analyses)

\begin{tabular}{|c|c|c|c|c|}
\hline Size & & $\begin{array}{l}\mathrm{P} 1 \\
60 \mu \mathrm{m}-2 \mathrm{~mm}\end{array}$ & $\begin{array}{l}\mathrm{P} 2 \\
>60 \mu \mathrm{m}\end{array}$ & $\begin{array}{l}\text { P3 } \\
<60 \mu \mathrm{m}\end{array}$ \\
\hline Shape & & Subhedral to euhedral & Subhedral to euhedral & Anhedral to subhedral: plane-parallel, truncated edge \\
\hline Porosity & & High & Low & Non- to slightly \\
\hline Inclusions & $\begin{array}{l}\leq 100 \mu \mathrm{m} \\
2-20 \mu \mathrm{m} \\
1-4 \mu \mathrm{m} \\
1-2 \mu \mathrm{m}\end{array}$ & $\begin{array}{l}\text { Qtz, anhedral, empty pores } \\
\text { Kfs, Ab, Cb, F-Ap, Fl, Ccp, REE } \\
\text { Brt, Po, Gn } \\
\text { Au-Ag }(9: 1) \text {, petzite }\end{array}$ & $\begin{array}{l}\text { Kfs, Ab, Qtz, empty pores } \\
\text { Petzite }\end{array}$ & Empty pores \\
\hline
\end{tabular}

Mineral abbreviations: $\mathrm{Ab}=$ albite, $\mathrm{Anh}=$ anhydrite, $\mathrm{Brt}=$ barite, $\mathrm{Cb}=$ carbonate, $\mathrm{Ccp}=$ chalcopyrite, $\mathrm{F}-\mathrm{Ap}=$ fluorapatite, $\mathrm{Fl}=$ fluorite, $\mathrm{Gn}=$ galena, $\mathrm{Kfs}=$ $\mathrm{K}$-feldspar, Po = pyrrhotite, Qtz = quartz, REE = rare earth element mineral 

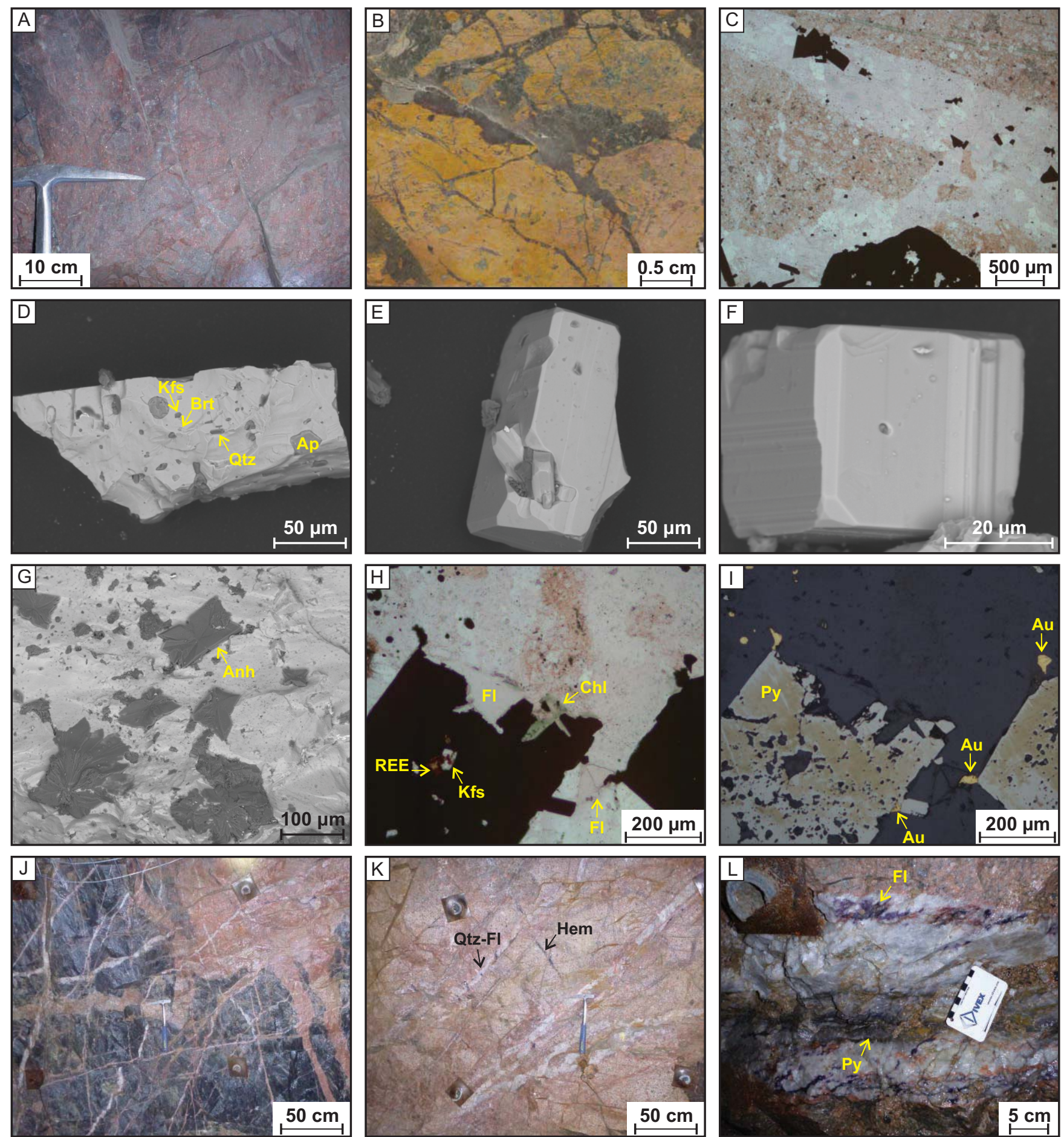

Fig. 6. Metasomatized mineralized zones: A) typical metasomatized ore zone; B) yellow staining enhancing the K-feldspar alteration and late brecciation by quartz veins in the Main zone; C) breccia in the Main zone, reddish colors are due to hematite dust; D) P1 pyrite with inclusions of K-feldspar, apatite, barite, and quartz-SEM; E) P2 pyrite-SEM; F) P3 pyriteSEM; G) anhydrite inclusions in $\mathrm{P} 1$ pyrite; $\mathrm{H}-\mathrm{I}$ ) native gold associated with fluorite and P1 pyrite with Ce-REE mineral and K-feldspar inclusions. Porphyry-style mineralization: J) well-developed stockwork and aplites in the volcaniclastic rocks; K) stockwork of hematite, quartz-fluorite, and quartz veins in the porphyritic facies of the O'Brien stock; and L) quartz-fluoritepyrite laminated vein in the porphyritic facies of the O'Brien stock. Anh = anhydrite, $\mathrm{Ap}=$ apatite, $\mathrm{Brt}=$ barite, $\mathrm{Chl}=$ chlorite, $\mathrm{Fl}=$ fluorite, Hem = hematite, $\mathrm{Kfs}=\mathrm{K}$-feldspar, $\mathrm{Py}=$ pyrite, $\mathrm{Qtz}=$ quartz . 
anhydrite, REE minerals; (2) sulfides: chalcopyrite, pyrrhotite, galena; (3) gold-bearing minerals: Au-Ag, Te-AuAg petzite, and some empty pores;

2. P2: Fine to coarse pyrite, greater than $60 \mu \mathrm{m}$, slightly porous, subhedral to euhedral. These have gangue mineral (K-feldspar, albite, quartz) and rare Te-Au-Ag petzite inclusions; some pores are empty;

3. P3: Very fine pyrite, less than $60 \mu \mathrm{m}$, non- to slightly porous, anhedral to subhedral. They display rare empty pores. When subhedral, they present a cubic or plane-parallel shape, with truncated edges.

Free gold occurs as nuggets $(<100 \mu \mathrm{m})$ in the mineralized zone matrix, at pyrite edges, and as inclusions within pyrite. These grains are $\mathrm{Ag}$ poor, 9:1 Au/Ag ratio, with no telluride. The Au-Ag ratio was measured on a few grains using an SEMEDS; this is consistent with metallurgical recovery at the mine (Au/Ag $\approx 8: 1$; Metanor Resources, pers. commun.).

The planar metasomatized ore zones are cut by several veinlets: (1) chlorite \pm carbonate veinlets cut P1 pyrites, (2) quartz tensile veins cut chlorite \pm carbonate veinlets, and (3) carbonate veinlets cut all the previous ones.

Alteration: In order to characterize the alteration in the ore zones, mass balance calculations were performed. Mineralized zones have the same REE profile as the altered volcanic host rocks (Fig. 3) and are considered to be metasomatized andesites and volcaniclastic rocks. In order to quantify gain and loss of elements with metasomatism, the less altered volcanic sample (based on microprobe observations and low LOI) is used as a precursor and the Grant isocon method is applied, where $\mathrm{Al}_{2} \mathrm{O}_{3}$ and $\mathrm{TiO}_{2}$ are considered immobile (Grant, 1986, 2005; Fig. 7). Two groups are identified: (1) red-type ore and (2) breccia-type ore. The same pattern of major elements gain and loss is displayed by the two ore types. Almost systematic loss in $\mathrm{Fe}_{2} \mathrm{O}_{3}, \mathrm{MgO}$, and $\mathrm{CaO}$ occurs, except in the Main zone for some higher grade samples where there is a $\mathrm{CaO}$ gain. There is a systematic $\mathrm{SiO}_{2}$ gain, reflecting the silicification within the mineralized zones. $\mathrm{Na}_{2} \mathrm{O}$ and $\mathrm{K}_{2} \mathrm{O}$ are also added; however, there is an inverted correlation between these alkali elements; there is either an important $\mathrm{Na}_{2} \mathrm{O}$ or $\mathrm{K}_{2} \mathrm{O}$ gain but not both at the same time. In extreme cases, an important $\mathrm{K}_{2} \mathrm{O}$ or $\mathrm{Na}_{2} \mathrm{O}$ gain induces an $\mathrm{Na}_{2} \mathrm{O}$ loss or $\mathrm{K}_{2} \mathrm{O}$ smaller gain, respectively. Therefore, the total alkali $\left(\mathrm{K}_{2} \mathrm{O}+\mathrm{Na}_{2} \mathrm{O}\right)$ gain is a better indicator of alkali alteration than the individual $\mathrm{K}_{2} \mathrm{O}$ and $\mathrm{Na}_{2} \mathrm{O}$ gain/loss. The difference between the two ore types is based on LREE and HREE mobility. The red-type ore has a strong REE enrichment whereas the breccia-type ore has none to slight REE enrichment. However, those variations are very local and the system is not zoned. For the red-type ore, the REE gains show atypical distribution. The LREE gains are decreasing from La to Eu; HREE gains are increasing from Eu to Lu. This REE mobility is not explained by

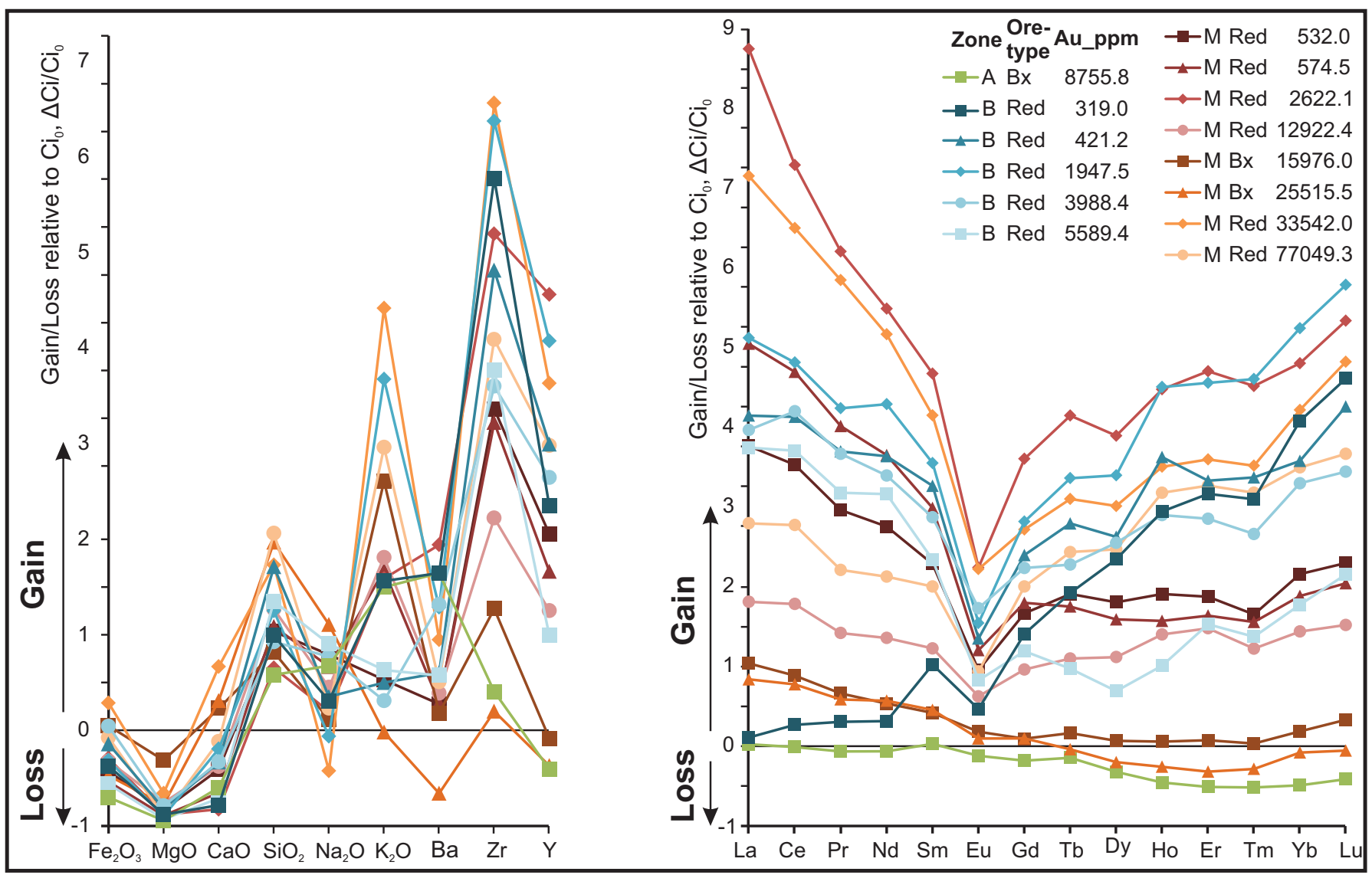

Fig. 7. Relative gain and loss in the mineralized zone compared to the less altered volcanic host rocks. Grant isocon method with $\mathrm{Al}_{2} \mathrm{O}_{3}$ and $\mathrm{TiO}_{2}$ considered immobile (Grant, 1986, 2005). A = A zone, $\mathrm{B}=\mathrm{B}$ zone, $\mathrm{Bx}=$ breccia-type ore, $\mathrm{M}=\mathrm{Main}$ zone, Red = red-type ore. 
classic mineral trapping where REE evolution is usually linear. Such atypical REE distribution remains poorly understood, although Monecke et al. (2011) suggested that it could result from unusual REE fractionation between liquid and vapor phases during a hydrothermal event in the presence of fluorine. Thus, the Ce-Nd-La-Pr-F-silico-calcic mineral observed in ore zones might have formed from LREE-enriched fluids.

Porphyry-style mineralization: The contact between the O'Brien stock and the host rocks is characterized by the presence of a well-developed stockwork (Figs. 4, 6). Four main vein types are distinguished (Table 5), presented here in chronological order: (1) rare massive hematite veins with feldspar selvages; (2) quartz only; (3) quartz with cryptocrystalline assemblage edges; (4) quartz-fluorite-pyrite-( $\mathrm{Au})$ veins. Quartz only and quartz-fluorite-pyrite-(Au) veins are equally present, and they account for about $90 \%$ of the veins. Most of these veins are narrow and long (1-4 cm $\times 1-6 \mathrm{~m})$. However, a few quartz-fluorite-pyrite-Au veins are thicker and laminated (i.e., 10-45 cm width), due to repeated opening events. Hematite veins are usually smaller, less than $2 \mathrm{~m}$ long. Hematite veins precede almost all other veins. Most often, quartz-only veins are cut by the quartz-fluorite-pyrite$\mathrm{Au})$ and quartz-cryptocrystalline mineral veins. The largest quartz-fluorite-pyrite-(Au) veins crosscut all others, and represent the latest event. Narrow aplites have mutually crosscutting relationships with all these veins; this is the latest felsic magmatism event.

Stereographic projection (Fig. 8) shows that the poles of the quartz-only veins fit on an almost E-W large circle; these veins trend NNW-SSE and are almost vertical. The poles of the quartz-fluorite and quartz-cryptocrystalline mineral veins also fit on a large circle, indicating that they probably formed at the same time, under the same stress conditions. These veins portray a wide range of orientations and dips, but three main families are inferred: (1) northwest veins; (2) north-northeast veins and (3) east veins. They cross each other in the southeast quadrant of the stereographic plot (Fig. 8). These three families have a fanlike distribution. The formation of these tension veins can be explained by applying a Hertzian stress model (Fig. 8c). As explained by Chai and Lawn (2005), the stress induced by a spherical object acting upon on a brittle object forms cracks with a conical distribution. Fluid pressure then causes the extension of these cracks to form tension veins. By analogy with this experiment, we propose that the emplacement of late plutonic phases into the volcanic and earlier plutonic phases is responsible for the initial push (Hertzian stress), and initiates cracking. Hydrothermal fluids then filled these cracks, and the fluid pressure caused the extension of these tension veins.

The quartz vein stockwork developed in two steps: (1) quartz-only veins parallel to the intrusion edges, possibly formed by the contraction of the magma during crystallization; and (2) quartz-fluorite and quartz-cryptocrystalline mineral veins, possibly formed as tension veins due to both pluton expansion and an increase in fluid pressure, allowing fractures to occur at a lower stress state.

Vein paragenesis in the porphyry stockwork of the Lac Bachelor mine appears to be clearly different from that in the classic Au-Cu porphyries described in Cordillera geology (Gustafson and Hunt, 1975; Sillitoe, 2010). The "M vein"
Table 5. Characteristics of the Porphyry-Style Veins

\begin{tabular}{|c|c|c|c|c|}
\hline Vein type & $\begin{array}{l}\text { Width } \\
(\mathrm{cm})\end{array}$ & $\begin{array}{l}\text { Length } \\
\text { (m) }\end{array}$ & Filling & Timing \\
\hline 1. Hematite & $1-3$ & $<2$ & $\begin{array}{l}\text { Massive hematite, } \\
\text { feldspar edges }\end{array}$ & \\
\hline 2. Quartz & $1-5$ & $1-3$ & Bulk quartz & \\
\hline 3. Quartz & 1 & $\begin{array}{l}0.2-1 \\
\text { rarely } \\
\text { up to } 6\end{array}$ & $\begin{array}{l}\text { Bulk quartz, } \\
\text { cryptocrystalline } \\
\text { assemblage edges }\end{array}$ & \\
\hline $\begin{array}{l}\text { 4. Quartz- } \\
\text { fluorite- } \\
\text { pyrite-(Au) }\end{array}$ & $\begin{array}{c}1-4 \\
15-45\end{array}$ & $\begin{array}{c}1 \\
2-5\end{array}$ & $\begin{array}{l}\text { Bulk quartz } \\
\text { Laminated, } \\
\text { bulk quartz }\end{array}$ & \\
\hline
\end{tabular}

equivalents are composed of hematite rather than magnetite. They are then crosscut by the quartz and quartz \pm fluorite \pm pyrite $\pm(\mathrm{Au})$ veins, which lack selvage alteration and could be interpreted as the "A veins" in terms of chronology; however, the mineral association is different. B and D veins are absent; Sillitoe (2010) previously noted such an absence in Au-rich porphyries. Variations in the abundance and facies of veins have also been observed in the Middle-Lower Yangtze River Valley intracontinental copper porphyry deposits (Zhou et al., 2015).

Paragenetic sequence: The paragenetic sequence (Fig. 9) is deduced from the mineralogy of metasomatized gold-rich zones, mineral relationships, such as inclusions and alteration, and the crosscutting vein relationships described in the previous section. The hydrothermal activity is divided into five stages.

1. Early silification: Early silicification formed small, slightly deformed quartz veins in the replacement zones.

2. Potassic pervasive metasomatism: Fluid then circulated through the volcanic host rocks along preexisting east-west discontinuities; the pervasive potassic alteration is characterized by the formation of magnetite and K-feldspars, which are then oxidized.

3. Martitization: This is the martitization of magnetite and hematite dusting stage. Oxidized F-rich fluids circulated and many accessory minerals (fluorite, barite, fluorapatite) precipitated into those replacement zones.

4. Sulfidation: Pyrite- and gold-bearing minerals then precipitated. At the same time, quartz \pm fluorite \pm cryptocrystalline assemblage \pm pyrite $\pm(\mathrm{Au})$ formed at the O’Brien stock-volcanic rocks contact.

5. Late brecciation and sericite-carbonate retrograde assemblage: Finally, there was retrograde sericitization, metasomatized ore zones were brecciated, and late quartz \pm carbonate \pm chlorite veins formed.

Rare large $(30-50 \mathrm{~cm})$ and long $(\geq 10 \mathrm{~m})$ white quartz veins with fragments of both intrusion and mineralized zones cutting through both host rocks and syenitic dikes represent a late hydraulic brecciation event.

Temperature estimate and fluid source: See (1994) studied fluid inclusions of quartz and fluorite in the O'Brien stock and mineralized zones. Two coexisting fluids, carbonic and 

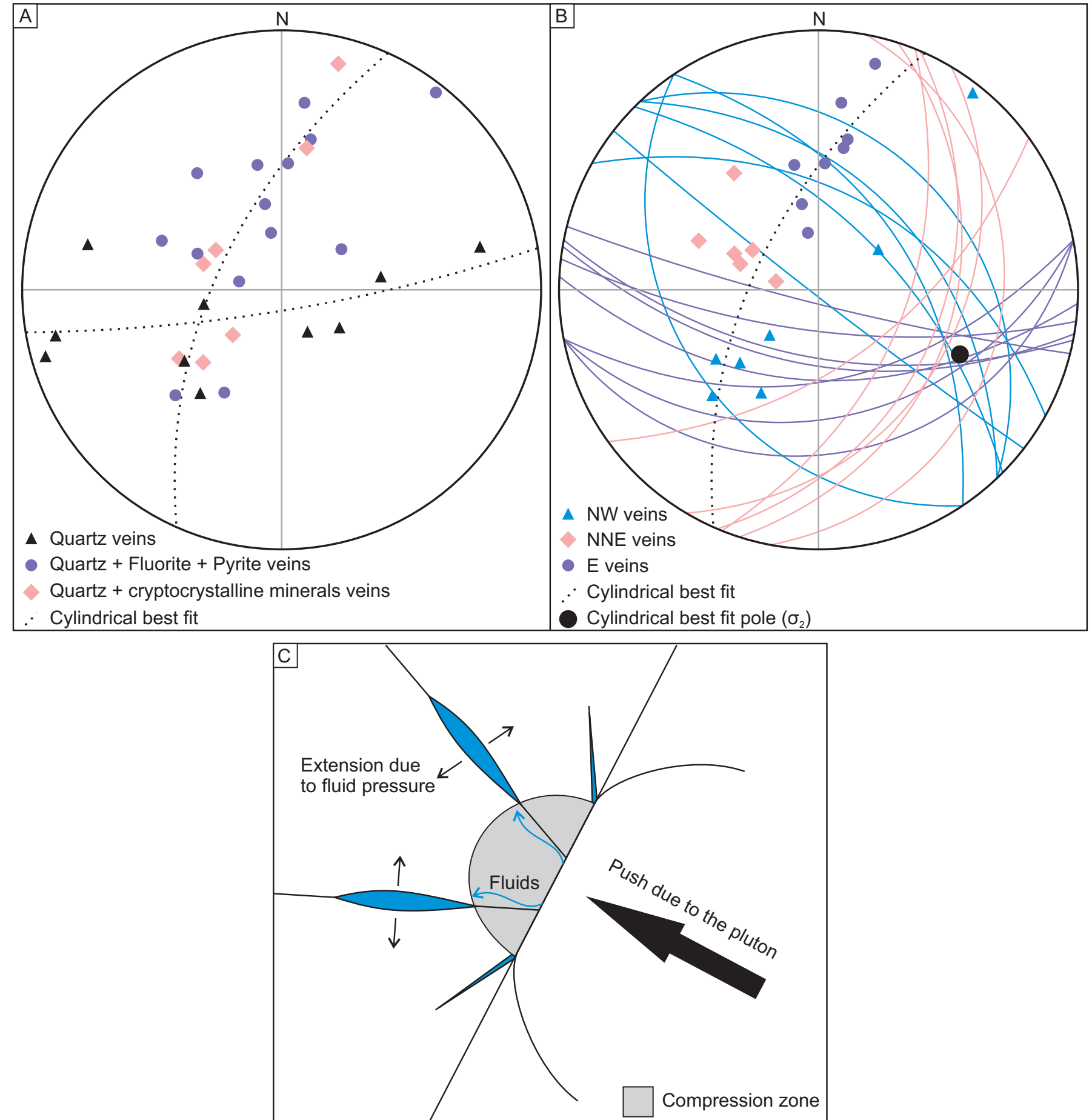

Fig. 8. A) Equal-angle stereographic projection showing poles of veins within the stockwork: (1) quartz-only veins; (2) quartz-fluorite-pyrite and quartz-cryptocrystalline mineral veins. B) Equal-angle stereographic projection of veins within the stockwork showing three families: (1) northwest veins; (2) north-northeast veins; and (3) east veins. C) Schematic cone crack model illustrating the formation of tension veins under Hertzian stresses due to the indentation of the host rocks by the pluton. Initial cracking is due to the push of the pluton; extension perpendicular to the veins is due to fluid pressure (modified from Chai and Lawn, 2005).

aqueous, were recognized. The temperature of vein formation was constrained between $275^{\circ}$ and $410^{\circ} \mathrm{C}$. With the use of $\delta^{18} \mathrm{O}$ and $\delta \mathrm{D}$ measurements performed on 22 of our samples, combined with the temperature estimation of See
(1994), the oxygen isotope composition for fluids at a mean temperature of about $340^{\circ} \mathrm{C}$ was calculated here. The oxygen and hydrogen isotope compositions for the Lac Bachelor deposit are reported in Table 6. Whatever the vein type, the 


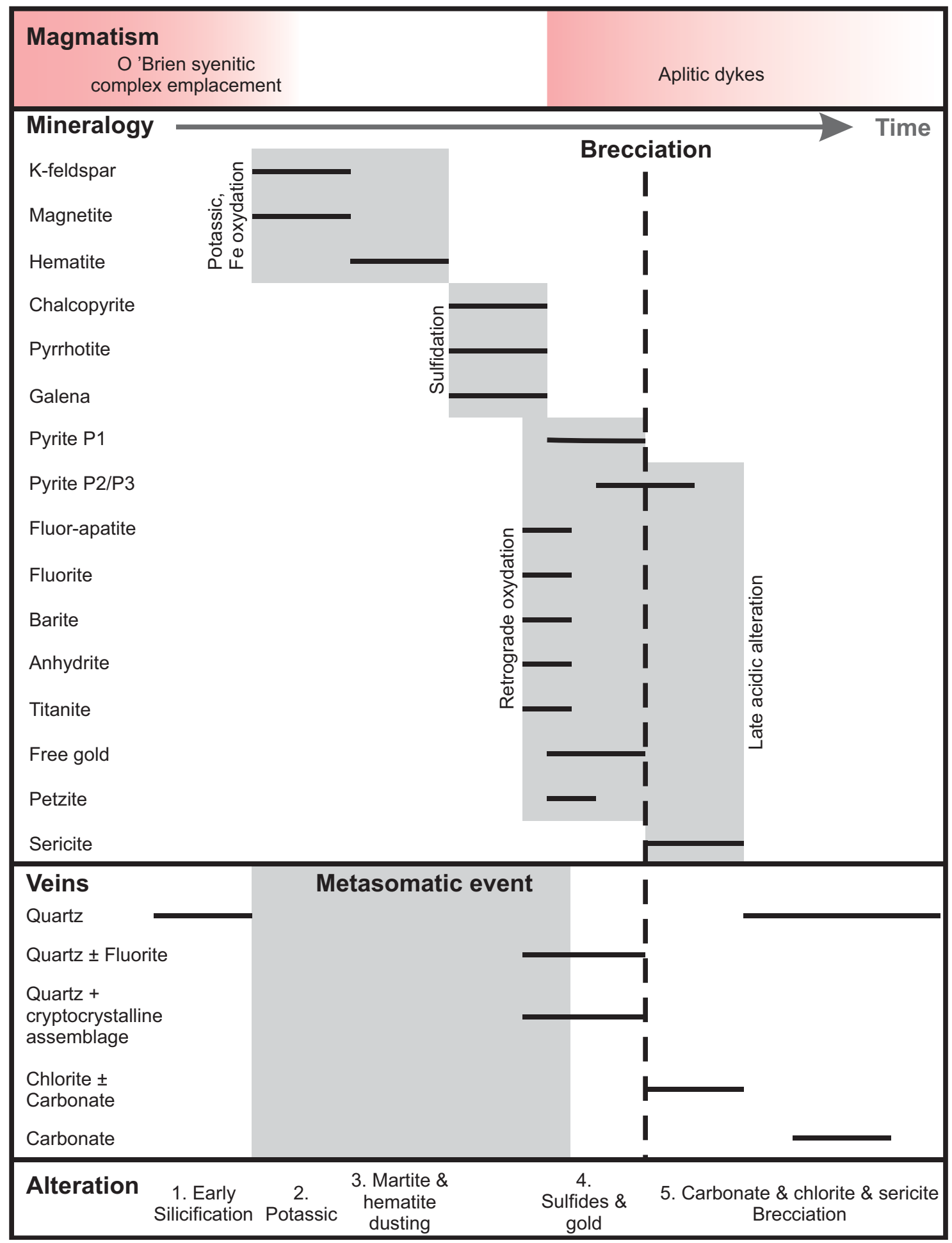

Fig. 9. Mineral paragenetic sequence at Lac Bachelor deposit with development of the red-type ore gold mineralization: (1) early silicification; (2) potassic pervasive metasomatism; (3) hematization; (4) sulfidation and gold precipitation; and (5) silica, carbonate, chlorite, and sericite alteration, both pervasive and brecciation.

$\delta \mathrm{D}$ is between -79 and $-40 \%$, corresponding to the range of magmatic fluids (McCuaig and Kerrich, 1998; Yardley and Bodnar, 2014). The $\delta^{18} \mathrm{O}$ values are more variable due to uncertainty regarding the temperature of formation. At $410^{\circ} \mathrm{C}$, all veins plot in the magmatic fluid field. At lower temperatures, $\delta^{18} \mathrm{O}$ values are lower, and in some cases, they plot outside the magmatic fluids field (Fig. 10). However, considering the composition of the veins (intrusive edges and 
Table 6. $\delta^{18} \mathrm{O}$ and $\delta \mathrm{D}$ Compositions of the Quartz Veins

\begin{tabular}{|c|c|c|c|c|c|c|}
\hline Sample no. & $\delta \mathrm{D}$ vs. VSMOW & $\delta^{18} \mathrm{O}$ vs. VSMOW & $\delta^{18} \mathrm{O}, 275^{\circ} \mathrm{C}$ & $\delta^{18} \mathrm{O}, 342.5^{\circ} \mathrm{C}$ & $\delta^{18} \mathrm{O}, 410^{\circ} \mathrm{C}$ & Vein type \\
\hline 17107 & -60 & 10.88 & 3.08 & 5.38 & 7.03 & \multirow[t]{9}{*}{ Quartz and cryptocrystalline assemblage } \\
\hline 23807 & -63 & 11.14 & 3.34 & 5.64 & 7.29 & \\
\hline 23812 & -52 & 12.13 & 4.33 & 6.63 & 8.28 & \\
\hline 23814 & -56 & 12.04 & 4.24 & 6.54 & 8.19 & \\
\hline 17117 & -74 & 11.60 & 3.80 & 6.10 & 7.75 & \\
\hline 17137 & -40 & 10.00 & 2.20 & 4.50 & 6.15 & \\
\hline 17138 & -51 & 10.10 & 2.30 & 4.60 & 6.25 & \\
\hline 17140 & -46 & 10.10 & 2.30 & 4.60 & 6.25 & \\
\hline 17143 & -60 & 9.90 & 2.10 & 4.40 & 6.05 & \\
\hline 23801 & -46 & 9.77 & 1.97 & 4.27 & 5.92 & \multirow[t]{5}{*}{ Qz-Fl-Py-(Au) } \\
\hline 23821 & -67 & 10.98 & 3.18 & 5.48 & 7.13 & \\
\hline 23822 & -58 & 11.35 & 3.55 & 5.85 & 7.50 & \\
\hline 17130 & -79 & 11.90 & 4.10 & 6.40 & 8.05 & \\
\hline 17139 & -49 & 13.60 & 5.80 & 8.10 & 9.75 & \\
\hline 23816 & -63 & 11.14 & 3.34 & 5.64 & 7.29 & \multirow[t]{3}{*}{ Quartz only, in the intrusion } \\
\hline 17125 & -47 & 12.30 & 4.50 & 6.80 & 8.45 & \\
\hline 17135 & -45 & 12.40 & 4.60 & 6.90 & 8.55 & \\
\hline 17144 & -73 & 10.0 & 2.20 & 4.50 & 6.15 & Quartz with intrusive edges in tuff \\
\hline 17123 & -67 & 13.50 & 5.70 & 8.00 & 9.65 & \multirow[t]{2}{*}{ Early quartz in mineralized zone } \\
\hline 17132 & -69 & 12.20 & 4.40 & 6.70 & 8.35 & \\
\hline 17122 & -67 & 13.00 & 5.20 & 7.50 & 9.15 & \multirow[t]{2}{*}{ Late quartz with intrusion and mineralized fragments } \\
\hline 17127 & -66 & 10.30 & 2.50 & 4.80 & 6.45 & \\
\hline
\end{tabular}

Notes: Calculated at $275^{\circ}, 342.5^{\circ}$, and $410^{\circ} \mathrm{C}$, according to temperature estimate by See (1994) and calculation by Matsuhisa et al. (1979)

purple fluorite) a magmatic origin of the fluids is more probable. All veins present the same $\delta \mathrm{D}$ and $\delta^{18} \mathrm{O}$ compositional range. This indicates that the fluid source is similar for all these veins, and therefore all hydrothermal events. The later white quartz vein, containing both mineralized zones and intrusions clasts, is derived from magmatic fluids. It represents the expulsion of residual fluids during the cooling of the magmatic-hydrothermal system.

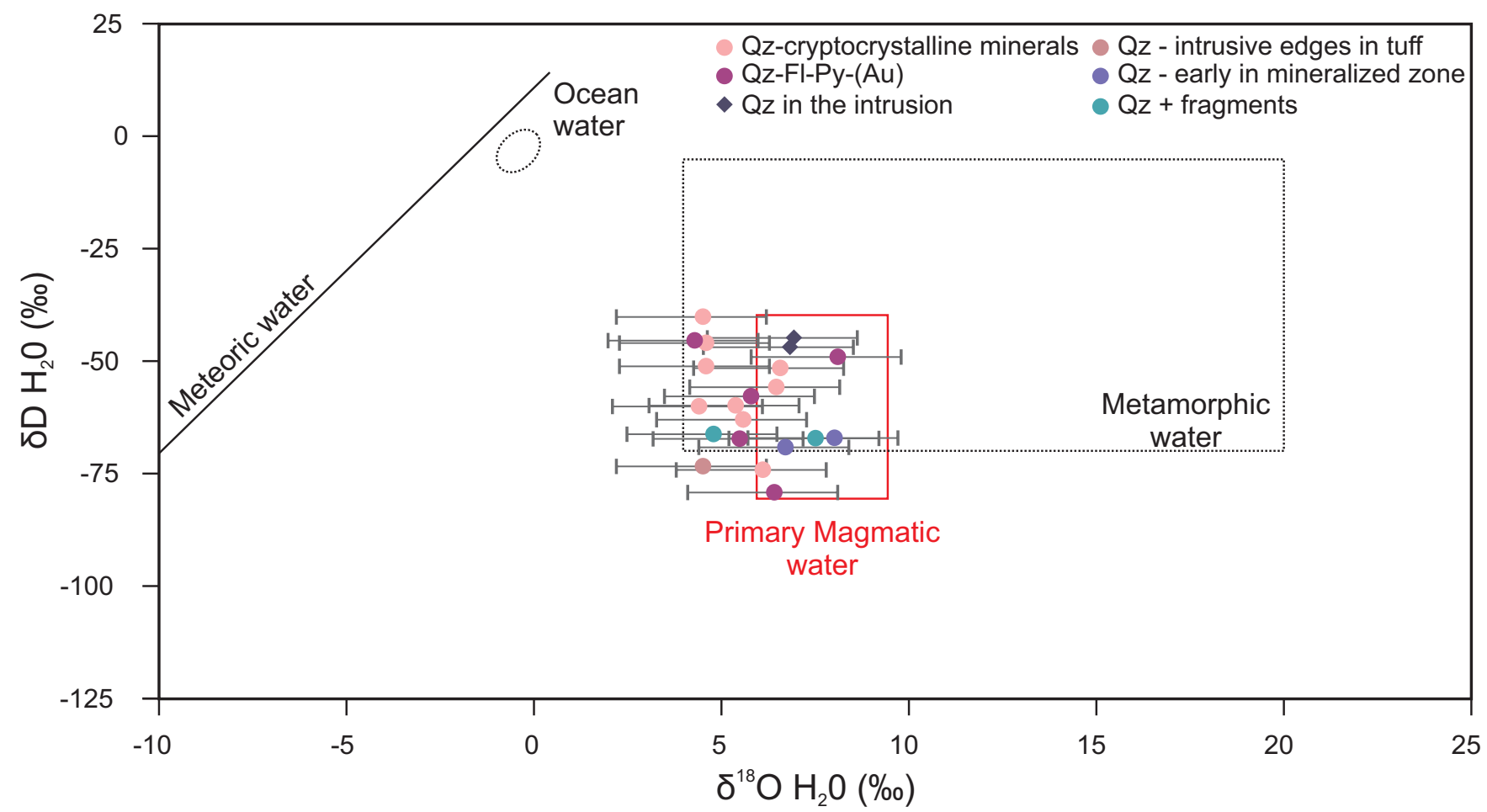

Fig. 10. Plot of the $\delta^{18} \mathrm{O}$ and $\delta \mathrm{D}$ isotopic composition ranges of the quartz veins. Compositions indicate a probable magmatic fluid source (modified from Yardley and Bodnar, 2014). 


\section{Discussion}

O'Brien stock: Petrological, geochemical, and P-T conditions

The intrusion of the O'Brien stock appears to be very surficial. Crystallization temperatures are estimated using the Miller et al. (2003) $\mathrm{Zr}$ thermometer and the zircon shape analysis method (Pupin and Turco, 1972; Pupin, 1980). In aplite and highly fractionated rocks such as the O'Brien stock, the zircon saturation temperature represents the minimal magma temperature at emplacement. In the case of inherited zircon, the temperature can be slightly overestimated (Miller et al., 2003). The O'Brien stock has a mean $\mathrm{Zr}$ content of $94.5 \mathrm{ppm}$, which corresponds to a temperature of about $735^{\circ} \mathrm{C}$. Using minimal and maximal $\mathrm{Zr}$ content, the magma emplacement temperature is constrained between $675^{\circ}$ and $760^{\circ} \mathrm{C}$ (Fig. 11). In the O'Brien stock, zircons are homogeneous and have a $\mathrm{T}$ index of 300 , corresponding to an approximate crystallization temperature of $600^{\circ}$ to $650^{\circ} \mathrm{C}$. They are interpreted to have formed at the end of crystallization (Pupin and Turco, 1972; Pupin, 1980). Such evaluations fit with previous data: See (1994) determined that melted inclusions reached saturated solidus between $650^{\circ}$ and $700^{\circ} \mathrm{C}$. Aqueous fluid inclusions were trapped at $675^{\circ} \mathrm{C}$. These different temperature determinations indicate that the magma intruded at a temperature ranging from $675^{\circ}$ to $760^{\circ} \mathrm{C}$, and cooled to the solidus point between $700^{\circ}$ and $650^{\circ} \mathrm{C}$ (Fig. 12). Such a low solidus temperature may be explained by the fluorine activity (Manning, 1981; Bouchez and Nédélec, 2011), which is high in the O'Brien stock, fluorapatite and interstitial purple fluorite being both presents (mean $\mathrm{F}=1,659 \mathrm{ppm}$ ).

The O'Brien stock includes albite, K-feldspar, and perthite. The presence of perthite is indicative of hypersolvus crystallization, whereas the presence of coexisting albite and K-feldspar suggests a subsolvus crystallization. Therefore,

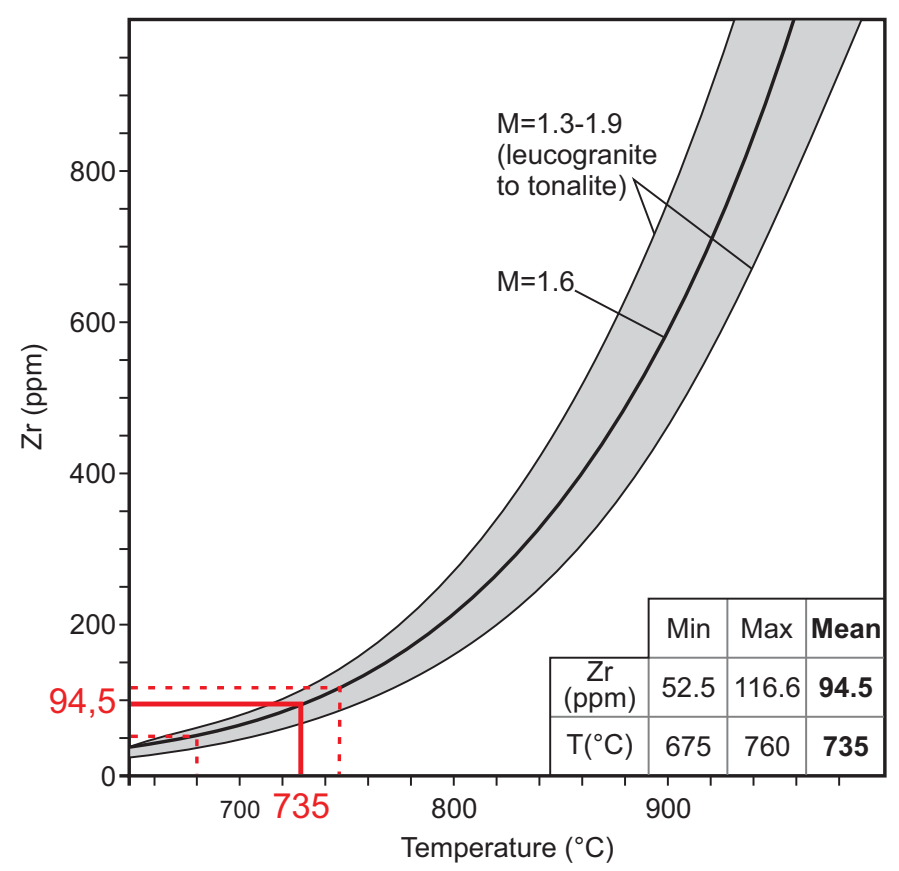

Fig. 11. Based on $\mathrm{Zr}$ content, temperature of the O'Brien magma intrusion is estimated at between $675^{\circ}$ and $735^{\circ} \mathrm{C}$ (modified from Miller et al., 2003).

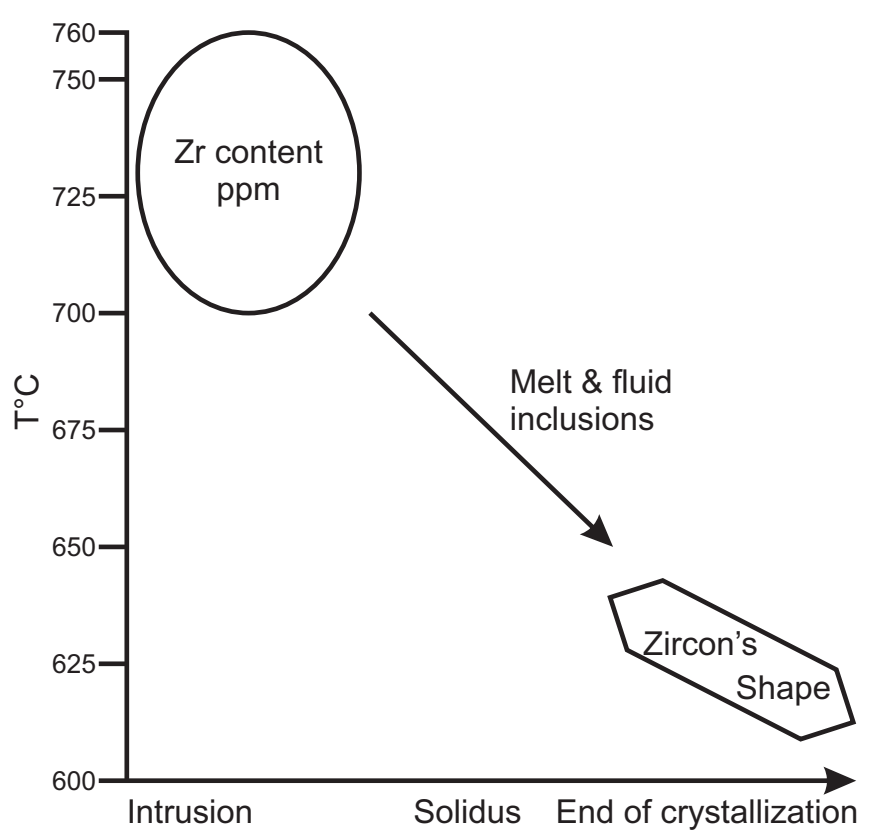

Fig. 12. O'Brien stock emplacement temperature, solidus, and end of crystallization is estimated from $\mathrm{Zr}$ concentration, melt and fluid inclusions (See, 1994), and zircon shape, respectively.

the combination of these three feldspars implies changes in the crystallization conditions, referred to here as transolvus (Bonin, 1990; Bouchez and Nédélec, 2011). The modification to a transolvus crystallization with albite $+\mathrm{K}$-feldspar + perthite paragenesis is triggered by the presence of fluorine (Manning, 1981). Transolvus crystallization and the presence of miaroles are indicative of low pressure and therefore magma intrusion at low depth.

The high fluorine activity in the magma lowers the viscosity and enables the segregation of a less viscous, enriched residual fluid (Dingwell, 1985; Bagdassarov et al., 1993; Bouchez and Nédélec, 2011), which can circulate more easily into the pluton and host rocks. This F-rich fluid often occurs as miaroles and hydrothermal veins in such systems (Webster et al., 1998). The miarole mineral assemblage-fluorite, fluorapatite, barite, calcite, and muscovite-reflects the composition of the hydrous fluid exsolved from the melt. As fluorine reduces the liquidus-solidus temperature, it increases the duration of the magmatic process (Dingwell, 1985). A long-term system and low viscosity favor the transition from a magmatic to a hydrothermal system.

\section{Age of gold mineralization}

The paragenetic sequence (Fig. 9) shows that the metasomatism event leading to the formation of replacement ore zones is divided into three main stages: (1) oxidation and potassic alteration; (2) sulfidation; and (3) retrograde oxidation, including pyrite and gold precipitation. The gold deposition therefore occurred late in the sequence. These three metasomatic events are constrained by the intrusion of the main O'Brien syenitic body, which is the starting point of this magmatichydrothermal system. The gold deposition occurs before and during the intrusion of aplitic dikes within the O'Brien syenite, the mineralized zones, and the volcanic host rock. 
The crosscutting relationship of the mineralized zone and the aplite supports the magmatic origin of the mineralizing fluids. This is also supported by the synchronous precipitation of gold, fluorite, fluorapatite, barite, and other minerals that are present in both mineralized zones and disseminated in the O’Brien syenite.

A late brecciation event took place during and after emplacement of the aplite dikes. However, there is no record of gold mineralization related to this event, and fluids still have a magmatic isotopic signature.

\section{Association of gold with an oxidized alkaline plutonic system}

The O'Brien stock is a polyphased alkali-calcic to alkaline intrusion, with composition ranging from quartz-syenite to alkali-granite. The alkalinity of this intrusion is confirmed by both geochemistry (absence of a europium anomaly, and strong LREE-HREE fractionation) and zircon shape. The presence of magnetite rather than ilmenite and the presence of sulfates at different stages of the magmatic-hydrothermal process are indicative of an oxidized system. Lack of a europium anomaly has frequently been observed in Archean alkaline igneous rocks and is often explained by the oxidized conditions under which those magmas crystallized (Cullers and Graf, 1984a, b; Rowins et al., 1993).

The O'Brien stock and metasomatized ore zones contain sulfates, barite, and anhydrite. In the intrusion, barite is observed in association with feldspar, apatite, and fluorite, in both groundmass and miaroles. In the mineralized zone, barite is present as inclusions within pyrite, and in the alkali feldspar matrix. This indicates that barite crystallized during both the magmatic and hydrothermal stages. Anhydrite occurs only as inclusions within pyrite, and supports precipitation during the hydrothermal stage. Numerous experimental and natural sample studies have been undertaken in order to understand the sulfur speciation in melts and fluids (Carroll and Rutherford, 1985; Metrich and Clocchiatti, 1996; Jugo, 2009; Baker and Moretti, 2011; WilliamsJones and Migdisov, 2014). The sulfur state, $\mathrm{S}^{2+}$ (sulfides) or $\mathrm{S}^{6+}$ (sulfates), in melts is dependent on several parameters: pressure, temperature, fluid composition, $\mathrm{FeO}$ content, $f_{\mathrm{O}_{2}}$, and $f_{\mathrm{S}_{2}}$ (Baker and Moretti, 2011). Although $f_{\mathrm{O}_{2}}$ is not the only parameter influencing the sulfide-sulfate transition, most studies demonstrate that sulfate saturation is reached at higher $f_{\mathrm{O}_{2}}$ than in sulfide saturation (Carroll and Rutherford, 1987; Metrich and Clocchiatti, 1996; Jugo, 2009; Baker and Moretti, 2011). In the O'Brien stock, sulfates are barite rather than anhydrite; the presence of barite over anhydrite can be explained by its greater stability in Ba-rich environments (Hattori, 1989; Hanor, 2000).

The europium anomaly is an estimate of the $\mathrm{Eu}^{2+} / \mathrm{Eu}^{3+}$ ratio (Drake and Weill, 1975). During the crystallization process, $\mathrm{Eu}^{2+}$ substitutes for $\mathrm{Ca}^{2+}$ and $\mathrm{Na}^{+}$in plagioclase; $\mathrm{Eu}^{3+}$, which is incompatible, stays in the residual magma (Henderson, 1984). In a feldspar-rich rock, such as a quartz-syenite, an anomaly is therefore expected. However, the O'Brien stock lacks any europium anomaly. Its absence reflects either a magmatic source with no plagioclase (Cullers and Graf, 1984a, b) or indicates an oxidized magma, where Eu is in the $\mathrm{Eu}^{3+}$ state (Drake and Weill, 1975). The presence of minerals indicative of high $f_{\mathrm{O}_{2}}$, such as magnetite-hematite-sulfates in the O'Brien stock, is consistent with a lack of the europium anomaly due to oxidation.

In order to estimate the $f_{\mathrm{O}_{2}}$ of mineralizing fluids in the Lac Bachelor deposit, See (1994) measured the composition$\mathrm{Fe}^{2+}, \mathrm{Fe}^{3+}, \mathrm{Mg}^{2+}$ - of hydrothermal biotite in equilibrium with magnetite and alkali-feldspar. Then, See (1994) used the calibrated curve of Wones and Eugster (1965) in $f_{\mathrm{O}_{2}}-\mathrm{T}$ space for biotite + K-feldspar + magnetite equilibrium to get a qualitative evaluation of oxygen fugacity. This method is still in use (Shabani et al., 2003; Rasouli and Shirzadi, 2017). Using this method, it was determined that the $f_{\mathrm{O}_{2}}$ of the fluid decreases with temperature as the system cools (See, 1994). The $f_{\mathrm{O}_{2}}$ lies between the quartz-fayalite-magnetite (QFM) and the hematite-magnetite (Hem-Mag) buffers (Fig. 13).

The O'Brien magnetite-hematite-rutile oxidized mineral association, the presence of sulfates, and the lack of a europium anomaly are consistent with an oxidized magma from which an oxidized fluid exsolved. This fluid is progressively reduced by interaction with host rocks and crystallization. Two coexisting mineralizing fluids were recognized (See, 1994): (1) a carbonic fluid, $\mathrm{H}_{2} \mathrm{O}-\mathrm{CO}_{2}-\mathrm{NaCl}\left( \pm \mathrm{CH}_{4}-\mathrm{H}_{2} \mathrm{~S}\right)$; and (2) an aqueous fluid, $\mathrm{H}_{2} \mathrm{O}-\mathrm{NaCl} \pm \mathrm{MgCl}_{2}$-KCl. Their moderate salinity $(3.3-14.55 \%)$, temperatures between $275^{\circ}$ and $410^{\circ} \mathrm{C}$, and pressure fluctuating from 110 and $310 \mathrm{MPa}$ are consistent with fluids exsolving from magma during crystallization.

The association between oxidized alkaline magmatism and gold deposits is recognized (Cameron and Hattori, 1987; Jensen and Barton, 2000; Sillitoe, 2000; Blevin, 2004) in both Proterozoic (e.g., Cripple Creek, USA; Ladolam, Papua New Guinea) and Archean (e.g., Boddington, Australia; YoungDavidson, Ontario; Beattie, Quebec) settings. Therefore, it is important to understand how this specific magmatism favored gold transport and deposition. Alkali magmas are derived from low degrees of partial melting, and are enriched in alkali $(\mathrm{Na}$, $\mathrm{K})$, volatile $(\mathrm{Cl}, \mathrm{F})$, and incompatible elements. Experimental

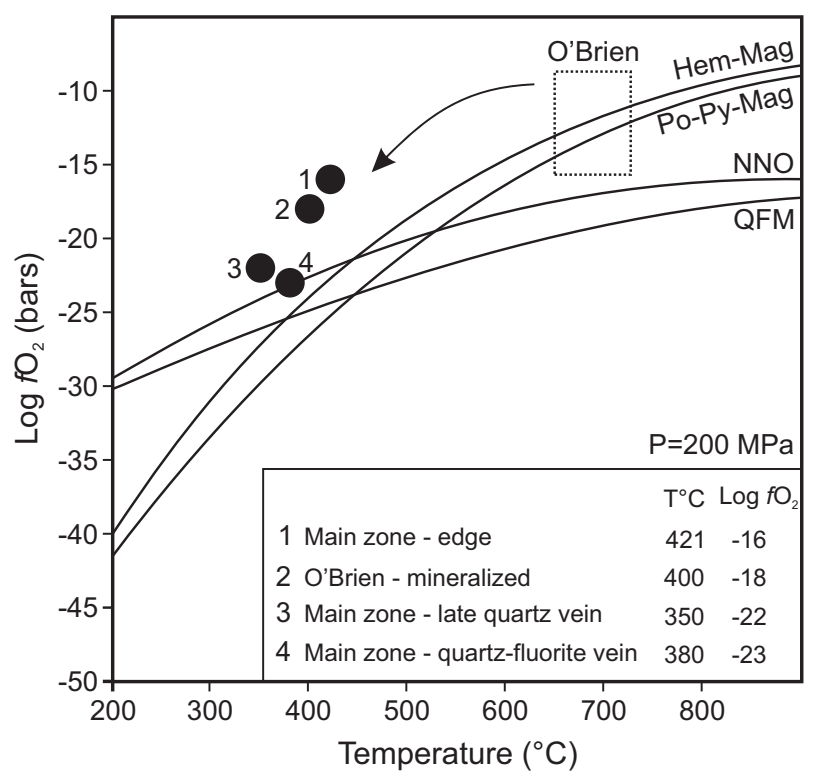

Fig. 13. Plots of the estimated oxygen fugacity $\left(f_{\mathrm{O}_{2}}\right)$ of the fluids show that the $f_{\mathrm{O}_{2}}$ decreases with temperature, and is above the magnetite-hematite buffer (modified from See, 1994). 
studies allow the role of oxidation, sulfur speciation, volatiles, and alkali content of melts in gold solubility and transport to be understood (Jugo, 2009; Botcharnikov et al., 2011; Pokrovski and Dubrovinsky, 2011).

The solubility of gold and other chalcophile elements is strongly dependent on the presence of ligands such as sulfur complexes. $\mathrm{HS}^{-}$and $\mathrm{H}_{2} \mathrm{~S}$ are recognized to be the main goldtransporting agents (Seward and Barnes, 1997), and in more oxidized hydrothermal fluids, $\mathrm{S}^{3-}$ is now a proposed ligand (Pokrovski and Dubrovinsky, 2011; Pokrovski and Dubessy, 2015). Therefore, sulfur solubility is a key factor, and conditions in which sulfur saturation is high should favor incorporation of gold in the magma during partial melting and further transportation. Partial melting under oxidizing conditions favors sulfide dissolution in the source magma, and therefore an increase in the initial concentration of gold and chalcophile elements (Mungall, 2002; Sun et al., 2015). Depending on the oxidation state of the fluid, sulfur is present as either sulfide or sulfate, and some studies have focused on the variation of sulfur solubility with oxidation; the highest sulfur solubility is reached when sulfide and sulfate saturation occurs simultaneously (Jugo, 2009). Therefore, melts with both sulfides and sulfates have a greater sulfur budget. However, a greater sulfur concentration does not always correlate with higher gold solubility, because Au does not have an equal affinity with all sulfur complexes. The higher Au solubility in melt occurs for moderately oxidized (FMQ+1) magma, when sulfur is present as both sulfide and sulfate, and at a low degree of partial melting (Botcharnikov et al., 2011). As gold forms complexes with sulfur, the early precipitation of sulfides has to be avoided; oxidizing conditions, above the FMQ buffer, is needed in order to allow the concentration of gold into residual melt and the aqueous phase during fractional crystallization of the magma (Mungall, 2002; Blevin, 2004).

The oxidation state during partial melting and later transport is a key factor, but in addition to being oxidized, many gold-bearing intrusions are alkaline. Regarding whether the presence of alkali elements influences gold solubility, recent studies have demonstrated that gold solubility increases in the presence of $\mathrm{Na}$ or $\mathrm{K}$ by forming $\mathrm{NaAuCl}_{2}, \mathrm{KAuCl}_{2}$, or, even better, $\mathrm{NaAu}(\mathrm{HS})_{2}$ and $\mathrm{KAu}(\mathrm{HS})_{2}$ complexes, which allow the efficient transfer of gold to magmatic fluids (Zajacz et al., 2010). Alkaline magmas are also enriched in volatile elements, and are fluorine rich, which favors the segregation of enriched hydrothermal fluids during a late stage of crystallization.

In conclusion, weakly oxidized (around FMQ+1), alkaline, and F-rich magmas encompass most of the optimal conditions for the following sequence: (1) gold and sulfur concentration in the melt during partial melting; (2) gold transportation and preservation during magma ascent; and (3) final concentration in residual F-rich hydrothermal fluids.

All of these conditions are met at the Lac Bachelor gold deposit. The presence of magnetite as well as both sulfides and sulfates, and $f_{\mathrm{O}_{2}}$ determination on biotite indicate a moderate oxidation state. The mineralogy (alkali-feldspar, fluorite) and the geochemistry of the O'Brien stock are consistent with an alkaline, F-rich composition. Finally, magmatic fluid exsolution at the end of the crystallization is confirmed by the presence of both metasomatized zones, indicative of pervasive fluid circulation, and quartz \pm fluorite \pm pyrite \pm Au veins stockwork of magmatic origin, revealing locally high fluid pressure.

As the crystallization and cooling of the intrusion progressed, residual aqueous fluid exsolved from the magma and percolated through the host rocks using preexisting faults as pathways. This oxidized magmatic fluid was enriched in fluorine, sulfur, and gold. The reaction between the fluid and host rocks changed the oxidation state of the fluid, allowing sulfide precipitation. Such reduction is needed to precipitate pyrite and associated gold (Cameron and Hattori, 1987; Mungall, 2002; Pokrovski and Dubrovinsky, 2011; Sun et al., 2015). At Lac Bachelor deposit, the Coniagas volcanogenic massive sulfide deposit, which is in very close proximity, might have accentuated the reducing character of the Fe-rich tholeiitic host rocks by locally adding sulfide to those rocks, prior to the O’Brien stock emplacement.

\section{A genetic model}

The development of an alkali magma by a low degree of partial melting and fractional crystallization allowed the separation of a highly evolved, $\mathrm{Fe}-\mathrm{Mg}$-poor granitic phase (i.e., the O'Brien quartz-syenite and alkali-granite) from a mafic residual phase. Lamprophyres in the Lac Bachelor area might have erupted from this later phase. The alkalic magma was enriched in fluorine and has a low viscosity, which allowed passive transport through the crust via a regional fault system and later emplacement via more local extensive structures.

The O'Brien stock sits in the unusual northeast-southwest Wedding-Lamarck deformation corridor, whereas most of the Archean breaks in the Abitibi subprovince are oriented east-west to west-northwest-east-southeast (Daigneault, 1996; Daigneault et al., 2002; Faure, 2012; Fayol et al., 2016). Several late-Archean alkaline intrusions (e.g., O’Brien, Lac Shortt) have been found along this corridor. This structure, as well as earlier, deep north-south and east-west crustal structures and subsidiary faults probably played an important role in magma migration through the crust. Preexisting faults acted as pathways for both magma and hydrothermal fluids. A magnetite-rich zone around the stock is responsible for the high magnetic signal around the intrusions (Fig. 14).

\section{Comparisons with other Archean porphyry systems}

Similar characteristics are observed in other gold deposits throughout the entire Abitibi subprovince (Table 1, Fig. 1). In the northern Abitibi, the Douay deposit is located on an E-W-trending fault. The syenitic complex is intrusive into intermediate to mafic volcanic rocks, and a magnetic halo is present (Fayol et al., 2016). High-grade gold mineralization is associated with metasomatized zones in the volcanic rocks and lower-grade mineralization with the intrusion itself (Dupéré and Gagnon, 2010; Cliff, 2012; Fayol et al., 2016). In the southern Abitibi, the Canadian Arrow deposit is located less than $10 \mathrm{~km}$ south of the Destor-Porcupine fault zone, at the intersection with the NE-trending Golden Arrow fault. The syenitic complex is intrusive into mafic volcanic rocks and a magnetic halo is also present. Gold is associated with strongly metasomatized, red-colored zones at the intrusion edges, and distribution is controlled by a preexisting NE-trending fault. Late hydraulic brecciation is also observed (Cherry, 1983; Lavigne, 2011; Fayol et al., 2016). 


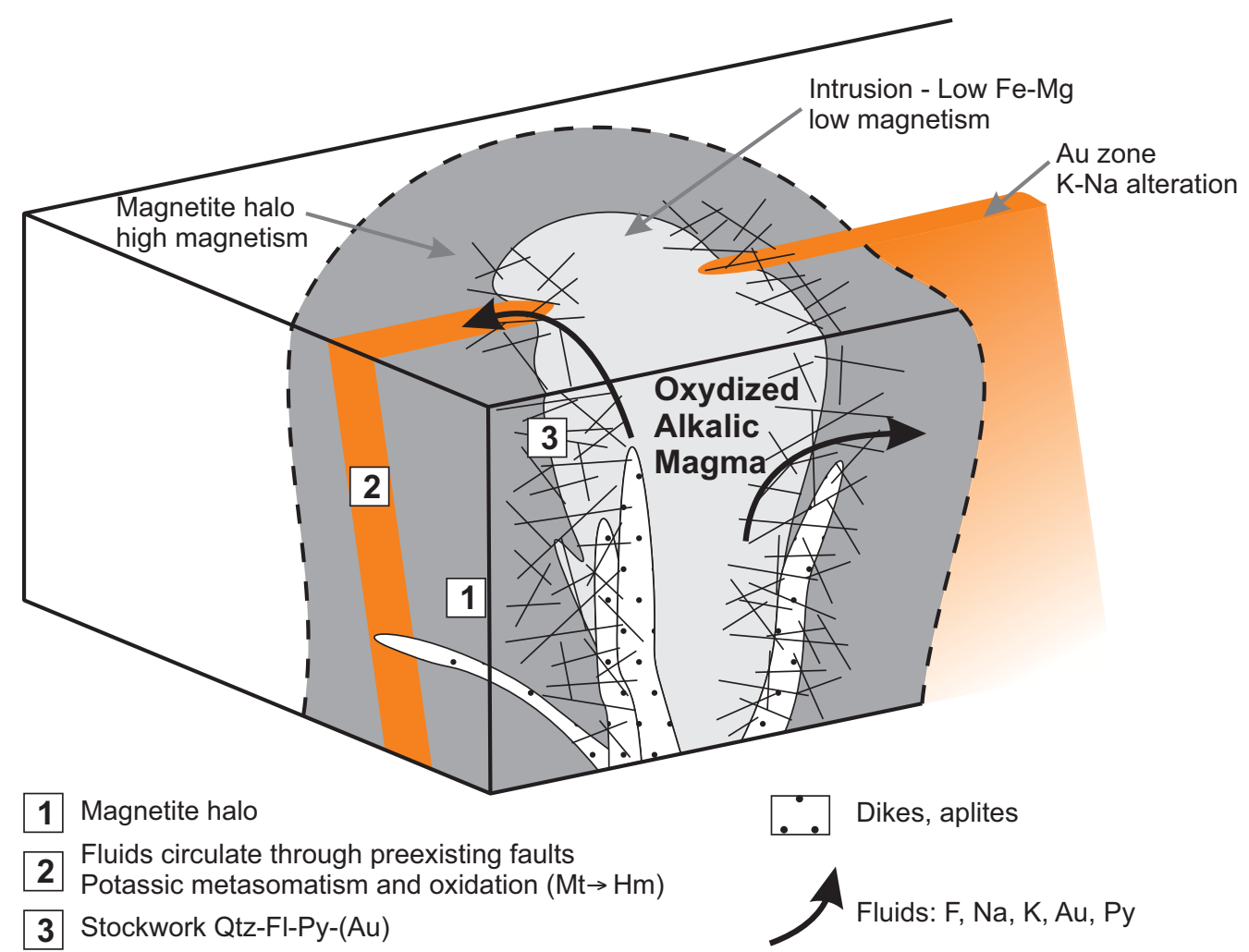

Fig. 14. Genetic model for late-Archean intrusion-related gold deposits showing the close relationship between an oxidizedalkaline intrusion and pervasive K-Na alteration of the host rocks. Hydrothermal fluid exsolved from the crystallizing pluton is enriched in alkali, volatiles, sulfur, and gold. Reduction of the fluid by the host rock induces sulfide and gold precipitation.

The largest gold deposit currently mined in the Abitibi greenstone belt is the Canadian Malartic, which is associated with an oxidized intrusion of the same posttectonic event as the O'Brien-Bachelor stock. The porphyritic monzonite intrusions range from subalkaline to alkaline (dacitic to andesitic and trachyandesitic; Helt et al., 2014). They belong to the same late tectonic, dominantly alkalic, and felsic to intermediate intrusions that are often associated with small intrusions of diorite, gabbro, clinopyroxenite, hornblendite, and lamprophyre (Frarey and Krogh, 1986; Corfu et al., 1989; Jemielita et al., 1990; Sutcliffe et al., 1993; Davis et al., 2000; Ayer et al., 2002). The Canadian Malartic dikes and sills are intrusive into metasedimentary rather than volcanic rocks, and alteration mineral assemblages are therefore locally different from those observed at the Lac Bachelor deposit. However, the alteration zones are still characterized by alkali metasomatism and the presence of hematite. A magmatic source for the fluids is proposed (Helt et al., 2014). The mineralization is mostly associated with the Cadillac-Larder Break fault that induces high complexity with multiple folding and shearing events (De Souza et al., 2015). As previously shown for Lac Bachelor deposit, potassium, fluorine, and carbonate appear as major indicators of the hydrothermal system (Gaillard et al., 2014). The Canadian Malartic mine belongs to the same family of Neoarchean sanukitoid-associated gold deposits and, therefore, Lac Bachelor appears to be a smaller and simpler version of the giant Canadian Malartic system. The giant Hemlo gold deposit has also been related to sanukitoid magmatism (Lin and Beakhouse, 2013).
Numerous deposits sharing similarities with Lac Bachelor have been encountered in other Archean cratons. In the Yilgarn block of Western Australia, several major gold deposits and prospects are associated with sanukitoids, including Lawlers, Kanowna Belle, Granny Smith, Liberty, Jupiter, Golden Cities, Mount Percy, Wallaby, and Porphyry (Champion and Sheraton, 1997; Duuring et al., 2007). The recently developed Tropicana gold deposit, located in the reworked margin of the Yilgarn craton in the Albany Fraser Proterozoic orogen, is also associated with the $2692 \pm 16 \mathrm{Ma}$ Hercules Gneiss of sanukitoid composition (Kirkland et al., 2015).

Sanukitoids are syn- to posttectonic minor intrusions that represent a very specific type of magma (Laurent et al., 2014); they are equivalent to the durbachite-vaugnerite series in the European Variscan orogen (Von Raumer et al., 2014). These $\mathrm{Mg-}, \mathrm{Fe}-$, and K-rich, metaluminous (monzo-) diorites and granodiorites occur after a subduction episode in recent orogens. Their dual geochemical character, i.e., richness in both "crustal" and "mantle" elements, results from the complex interactions at the mantle level between peridotite and an incompatible element-rich component (Almeida et al., 2010; Laurent et al., 2014). Several geodynamic configurations could explain a particular feature such as the partial melting of a subduction-enriched subarc mantle during a late, lower crustal delamination of the orogen (Smithies and Champion, 1999; Bédard and Harris, 2014). The Lac Bachelor gold deposit would therefore represent a key element to understanding gold metallogeny at the end of the Archean. 


\section{Conclusions}

In the Abitibi subprovince, late-Archean intrusion-related gold deposits are mainly located in the vicinity of major breaks. These structures have long been studied in order to propose tectonic models for the Abitibi subprovince construction, to unravel the Timiskaming sedimentary basin formation or the hydrothermal fluid circulation (e.g., modeling of low pressure areas after a seismic event along the break; Faure and Rafini, 2004). However, the presence of magmatic gold deposits in east-west, north-south, and northwest-southeast deformation corridors indicates that such structures only act as pathways for ascendant alkaline magmas through the crust, and that a single structural approach is not enough to understand the genesis of intrusion-related gold deposits.

The Lac Bachelor gold deposit is located at the edges of a syenitic complex that is surrounded by a magnetic halo (Fig. 4). The evolved sanukitoid composition of the pluton reflects the remelting of an early enriched mantle, followed by fractionation during which gold is extracted from the magma and migrates into the hydrothermal fluid. Gold is associated with pyrite in alkaline, fluorite, and hematite-rich pervasive metasomatized zones in the magnetite-rich volcanic host rocks.

To form such deposits, the following conditions must be met: (1) alkaline-oxidized magmatism, which favors sulfur and gold solubility and transport; (2) crustal discontinuities, allowing migration of such magma through the crust; (3) high permeability in the host rocks to allow hydrothermal fluid circulation and metasomatism reactions around the pluton; and (4) oxido-reduction contrast between the fluid and the host rocks, causing gold deposition. Such gold deposits are developed during the waning stage of deformation in an orogenic belt and are strongly associated with a plutonic event. The relationship of these deposits with the most evolved (low $\mathrm{Fe}-\mathrm{Mg}$, high $\mathrm{SiO}_{2}$ ) end-member intrusions of the sanukitoid sensu lato clan, as defined by Laurent et al. (2014) in Precambrian greenstone belts, suggests that gold could have been scavenged from the sanukitoid source zone (interaction of crustal and mantle melts), and extracted from the magma during differentiation to be deposited around the intrusion.

\section{Acknowledgments}

This research was supported by the Natural Sciences and Engineering Research Council of Canada (NSERC), and the Fonds de Recherche du Québec-Nature et Technologies (FQRNT). We thank Metanor Resources Inc. and its teams for the funding, easy access to the mine, datasets, and discussions.

\section{REFERENCES}

Allard, G.O., Duquette, G., Latulippe, M., Van de Walle, M., Brown, A., Guilloux, L., and Lasalle, P., 1972, Precambrian geology and mineral deposits of the Noranda-Val d'Or and Matagami-Chibougamau greenstone belts, Quebec: International Geological Congress, 24 ${ }^{\text {th }}$, Montreal, Quebec, Guidebook for Excursion A41 and C41, p. 58-61.

Almeida, J.d.A.C., Dall'Agnol, R., Dias, S.B., and Althoff, F.J., 2010, Origin of the Archean leucogranodiorite-granite suites: Evidence from the Rio Maria terrane and implications for granite magmatism in the Archean: Lithos, v. 120 , p. 235-257.

Ayer, J., Amelin, Y., Corfu, F., Kamo, S., Ketchum, J., Kwok, K., and Trowell, N., 2002, Evolution of the southern Abitibi greenstone belt based on U-Pb geochronology: Autochthonous volcanic construction followed by plutonism, regional deformation and sedimentation: Precambrian Research, v. 115 , p. $63-95$.
Bagdassarov, N., Dingwell, D.B., and Webb, S.L., 1993, Effect of boron, phosphorus and fluorine on shear stress relaxation in haplogranite melts: European Journal of Mineralogy, v. 5, p. 409-425.

Baker, D.R., and Moretti, R., 2011, Modeling the solubility of sulfur in magmas: A 50-year-old geochemical challenge: Reviews in Mineralogy and Geochemistry, v. 73, p. 167-213.

Bedard, J.H., and Harris, L.B., 2014, Neoarchean disaggregation and reassembly of the Superior craton: Geology, v. 42, p. 951-954.

Bedard, J.H., Harris, L.B., and Thurston, P.C., 2013, The hunting of the snArc: Precambrian Research, v. 229, p. 20-48.

Bigot, L., and Jébrak, M., 2015, Gold mineralization at the syenite-hosted Beattie gold deposit, Duparquet, Neoarchean Abitibi belt, Canada: Economic Geology, v. 110, p. 315-335.

Blevin, P.L., 2004, Redox and compositional parameters for interpreting the granitoid metallogeny of eastern Australia: Implications for gold-rich ore systems: Resource Geology, v. 54, p. 241-252.

Bonin, B., 1990, Les granites des complexes annulaires: Bureau de Recherches Géologiques et Minières (BRGM), Manuels \& Méthodes, no. 4, 183 p.

Botcharnikov, R.E., Linnen, R.L., Wilke, M., Holtz, F., Jugo, P.J., and Berndt, J., 2011, High gold concentrations in sulphide-bearing magma under oxidizing conditions: Nature Geoscience, v. 4, p. 112-115.

Bouchez, J.-L., and Nédélec, A., 2011, Pétrologie des granites, Structurecadre géologique: Paris, Vuibert, 320 p.

Brisson, H., 1998, Caractéristiques, chronologie et typologie des minéralisations aurifères de la région du Lac Shortt (Québec), sous-province archéenne de l'Abitibi, Chicoutimi: PhD thesis, Université du Québec à Chicoutimi, 296 p.

Buro, Y.A., 1984, Geology of the Bachelor Lake gold mine, Desmaraisville, Abitibi-East, Québec: Canadian Institute of Mining, Metallurgy and Petroleum, CIM Special Volume 34, p. 385-392.

Cameron, E.M., and Hattori, K., 1987, Archean gold mineralization and oxidized hydrothermal fluids: Economic Geology, v. 82, p. 1177-1191.

Carroll, M.R., and Rutherford, M.J., 1985, Sulfide and sulfate saturation in hydrous silicate melts: Journal of Geophysical Research, Solid Earth, v. 90, p. C601-C612.

1987, The stability of igneous anhydrite: Experimental results and implications for sulfur behavior in the $1982 \mathrm{El}$ Chichon trachyandesite and other evolved magmas: Journal of Petrology, v. 28, p. 781-801.

Chai, H., and Lawn, B.R., 2005, Hydraulically pumped cone fracture in brittle solids: Acta Materialia, v. 53, p. 4237-4244.

Champion, D.C., and Sheraton, J.W., 1997, Geochemistry and Nd isotope systematics of Archaean granites of the Eastern Goldfields, Yilgarn craton, Australia: Implications for crustal growth processes: Precambrian Research, v. 83 , p. $109-132$.

Charbonneau, J.-M., Picard, C., and Dupuis-Hébert, L., 1983, ET 82-01 Géologie des unités stratigraphiques affleurant dans les cantons de Daubrée, Dolomieu, Saussure et La Ribourde, Abitibi-Est.: Ministère des Respurces Naturelles du Québec, 67 p.

Cherry, M.E., 1983, The association of gold and felsic intrusions-examples from the Abitibi belt: Ontario Geological Survey, Miscellaneous Paper 110, p. $48-55$.

Chown, E.H., Daigneault, R., Mueller, W., and Mortensen, J.K., 1992, Tectonic evolution of the Northern volcanic zone, Abitibi belt, Quebec: Canadian Journal of Earth Sciences, v. 29, p. 2211-2225.

Chown, E.H., Harrap, R., and Moukhsil, A., 2002, The role of granitic intrusions in the evolution of the Abitibi belt, Canada: Precambrian Research, v. 115 , p. $291-310$.

Cliff, D.P., 2012, Douay deposit NI 43-101 compliant technical report for Société minière Aurvista, http://www.sedar.com, 162 p.

Corfu, F., Krogh, T.E., Kwok, Y.Y., and Jensen, L.S., 1989, U-Pb zircon geochronology in the southwestern Abitibi greenstone belt, Superior province: Canadian Journal of Earth Sciences, v. 26, p. 1747-1763.

Cullers, R.L., and Graf, J.L., 1984a, Rare earth elements in igneous rocks of the continental crust: Predominantly basic and ultrabasic rocks, in Henderson, P., ed., Developments in Geochemistry, Volume 2: Elsevier, p. 237-274.

-1984b, Rare earth elements in igneous rocks of the continental crust: Intermediate and silicic rocks — ore petrogenesis, in Henderson, P., ed., Developments in Geochemistry, Volume 2: Elsevier, p. 275-316.

Daigneault, R., 1996, Couloirs de déformation de la Sous-Province de l'Abitibi: Ministère de l'Énergie et des Mines du Québec, MB 96-33, 140 p.

Daigneault, R., St-Julien, P., and Allard, G.O., 1990, Tectonic evolution of the northeast portion of the Archean Abitibi greenstone belt, Chibougamau area, Quebec: Canadian Journal of Earth Sciences, v. 27, p. 1714-1736. 
Daigneault, R., Mueller, W.U., and Chown, E.H., 2002, Oblique Archean subduction: Accretion and exhumation of an oceanic arc during dextral transpression, Southern volcanic zone, Abitibi subprovince Canada: Precambrian Research, v. 115, p. 261-290.

Darling, P., and Lafontaine, M., 2011, NI 43-101 technical report Bachelor Lake gold project for Ressources Métanor Inc., http://www.sedar.com, 229 p.

David, J., Davis, D.W., Dion, C., Goutier, J., Legault, M.I., and Roy, P., 2007, Datations U-Pb effectuées dans la Sous-province de l'Abitibi en 20052006: Ministère des Ressources Naturelles et de la Faune du Québec, RP 2007-01, 17 p.

Davis, W.J., Lacroix, S., Gariépy, C., and Machado, N., 2000, Geochronology and radiogenic isotope geochemistry of plutonic rocks from the central Abitibi subprovince: significance to the internal subdivision and plutonotectonic evolution of the Abitibi belt: Canadian Journal of Earth Sciences, v. 37, p. 117-133.

De Souza, S., Dubé, B., McNicoll, V.J., Dupuis, C., Mercier-Langevin, P., Creaser, R.A., and Kjarsgaard, I.M., 2015, Geology, hydrothermal alteration, and genesis of the world-class Canadian Malartic stockwork-disseminated Archean gold deposit, Abitibi, Quebec: Geological Survey of Canada, Open File 7852, p. 113-126.

Dingwell, D.B., 1985, The structure and properties of fluorine-rich magmas: A review of experimental studies: The Canadian Institute of Mining and Metallurgy, Special Volume 39, p. 1-12.

Doucet, P., 1993, Caractérisation de l'environnement volcanique du gisement de Coniagas, Desmaraisville-District de Chibougamau: Ministère de l'Énergie et des Mines du Québec, MB 93-46, 52 p.

Doucet, P., Mueller, W.U., and Chartrand, F., 1994, Archean, deep-marine, volcanic eruptive products associated with the Coniagas massive sulfide deposit, Quebec, Canada: Canadian Journal of Earth Sciences, v. 31, p. 1569-1584.

Doucet, P., Mueller, W., and Chartrand, F., 1995, Environnement volcanique, géochimie et minéralisation du gisement de Coniagas, Desmaraisville: Ministère de l'Énergie et des Mines du Québec, MB 95-14, 112 p.

Doucet, P., Mueller, W.U., and Chartrand, F., 1998, Alteration and ore mineral characteristics of the Archean Coniagas massive sulfide deposit, Abitibi belt, Quebec: Canadian Journal of Earth Sciences, v. 35, p. 620-636.

Drake, M.J., and Weill, D.F., 1975, Partition of Sr, Ba, Ca, Y, $\mathrm{Eu}^{2+}, \mathrm{Eu}^{3+}$, and other REE between plagioclase feldspar and magmatic liquid: an experimental study: Geochimica et Cosmochimica Acta, v. 39, p. 689-712.

Dupéré, M., and Gagnon, G., 2010, NI 43-101 Preliminary economic assessment of the Douay West mineral deposit for Société d'exploration minière Vior inc., http://www.sedar.com, 106 p.

Duuring, P., Cassidy, K.F., and Hagemann, S.G., 2007, Granitoid-associated orogenic, intrusion-related, and porphyry style metal deposits in the Archean Yilgarn craton, Western Australia: Ore Geology Reviews, v. 32, p. 157-186.

Faure, S., 2011, Le Corridor metallogenique de Lebel-sur-Quevillon/ Lac Shortt (Abitibi): Consortium de recherche exploration en minérale (CONSOREM), Projet 2010-03, 33 p.

2012, Réévaluation de la géologie et des modèles d'exploration pour l'or dans le segment Caopatina-Desmaraisville, sud de Chibougamau: Consortium de recherche exploration en minérale (CONSOREM), Projet 2012$02,57 \mathrm{p}$.

Faure, S., and Rafini, S., 2004, Modélisation des paléocontraintes et des paléopressions le long de la faille Porcupine-Destor-implication pour la formation de bassins sédimentaires, d'intrusions et de minéralisations aurifères: Consortium de recherche exploration en minérale (CONSOREM), Projet 2003-03, 53 p.

Fayol, N., 2016, Neoarchean alkaline intrusion-related gold deposits of the Abitibi subprovince, Canada. Example of the Lac Bachelor gold deposit, Abitibi-Genetic model and exploration targeting: PhD thesis, Université du Québec à Montréal, 215 p.

Fayol, N., Harris, L.B., and Jébrak, M., 2012, The role of crustal heterogeneities in the localization of the Desmaraisville basin (Quebec Abitibi) established from regional geophysics and analogue modelling [ext. abs.]: GeoMod 2012 conference, Lausanne, Switzerland, July 5-20, 2012, 2 p.

Fayol, N., Jébrak, M., and Harris, L.B., 2013, Gold associated with Neoarchean alkaline intrusion, Lac Bachelor, Abitibi, Canada: Mineralogical Magazine, v. 77, p. 1068.

2016, The magnetic signature of Neoarchean alkaline intrusions and their related gold deposits: Significance and exploration implications: Precambrian Research, v. 283, p. 13-23.
Franklin, J.M., and Thorpe, R.I., 1982, Comparative metallogeny of the Superior, Slave and Churchill provinces: Geological Association of Canada Special Paper 25, p. 1-90.

Frarey, M.J., and Krogh, T.E., 1986, U-Pb zircon ages of later internal plutons of the Abitibi and eastern Wawa subprovinces, Ontario and Québec: Geological Survey of Canada, Paper 86-1A, p. 43-48.

Gaillard, N., Williams-Jones, A.E., Salvi, S., Béziat, D., Clark, J.R., Perrouty, S., Linnen, R., Olivo, G.R., and Wares, R.P., 2014, Investigating the footprint of the Canadian Malartic gold deposit: mineralogical and geochemical constraints, SEG Conference, abstract 0393-000187.

Galley, A., 2003, Composite synvolcanic intrusions associated with Precambrian VMS-related hydrothermal systems: Mineralium Deposita, v. 38, p. $443-473$.

Gervais, D., Roy, C., Thibault, A., Pednault, C., and Doucet, D., 2014, NI 43-101 technical report for Mines Agnico Eagle Limitée on the mineral resource and mineral reserve estimates for the Canadian Malartic property, http://www.sedar.com, $460 \mathrm{p}$.

Goutier, J., and Melançon, M., 2010, Compilation géologique de la Sous-province de l'Abitibi: Ministère de l'Énergie et des Mines du Québec, RP 2010-04, 1 p.

Graham, R.B., 1957, Partie Sud-Ouest du canton de Lesueur, District électoral d'Abitibi-Est, Ministère de l'Énergie et des Mines du Québec, RG $072,37 \mathrm{p}$.

Grant, J.A., 1986, The isocon diagram; a simple solution to Gresens' equation for metasomatic alteration: Economic Geology, v. 81, p. 1976-1982.

2005, Isocon analysis: A brief review of the method and applications: Physics and Chemistry of the Earth, Parts A/B/C, v. 30, p. 997-1004.

Groves, D.I., Goldfarb, R.J., Gebre-Mariam, M., Hagemann, S.G., and Robert, F., 1998, Orogenic gold deposits: A proposed classification in the context of their crustal distribution and relationship to other gold deposit types: Ore Geology Reviews, v. 13, p. 7-27.

Groves, D.I., Goldfarb, R.J., Robert, F., and Hart, C.J.R., 2003, Gold deposits in metamorphic belts: Overview of current understanding, outstanding problems, future research, and exploration significance: Economic Geology, v. 98, p. 1-29.

Gustafson, L.B., and Hunt, J.P., 1975, The porphyry copper deposit at El Salvador, Chile: Economic Geology, v. 70, p. 857-912.

Hanor, J.S., 2000, Barite-celestine geochemistry and environments of formation: Reviews in Mineralogy and Geochemistry, v. 40, p. 193-275.

Harris, L.B., and Bédard, J.H., 2014, Crustal evolution and deformation in a non-plate-tectonic Archaean Earth: Comparisons with Venus, in Dilek, Y., and Furnes, H., eds., Evolution of Archean crust and early life: Netherlands, Springer, Modern Approaches in Solid Earth Sciences, v. 7, p. 215-291.

Hattori, K., 1987, Magnetic felsic intrusions associated with Canadian Archean gold deposits: Geology, v. 15, p. 1107-1111.

1989, Barite-celestine intergrowths in Archean plutons; the product of oxidizing hydrothermal activity related to alkaline intrusions: American Mineralogist, v. 74, p. 1270-1277.

Helt, K.M., Williams-Jones, A.E., Clark, J.R., Wing, B.A., and Wares, R.P., 2014, Constraints on the genesis of the Archean oxidized, intrusion-related Canadian Malartic gold deposit, Quebec, Canada: Economic Geology, v. 109 , p. $713-735$.

Henderson, P., 1984, General geochemical properties and abundances of the rare earth elements, in Henderson, P., ed., Developments in Geochemistry, Volume 2: Elsevier, p. 1-32.

Jébrak, M., 2011, Archean gold porphyry deposits of the Abitibi greenstone belt, Québec, Canada-possible role of late orogenic sedimentary rocks [abs.]: Society for Geology Applied to Mineral Deposits (SGA), 11th biennial meeting, Antofagasta, Chile, September 26-29, 2011, Proceedings, p. 334-336.

Jébrak, M., and Fayol, N., 2015, The late-Archean magmatic gold event: Toward a non-uniformitarian approach [ext. abs.]: Society for Geology Applied to Mineral Deposits (SGA),13th biennial meeting, Nancy, France, August 24-27, 2015, Proceedings, v. 1, p. 125-128.

Jébrak, M., and Marcoux, E., 2015, Geology of mineral resources: Geological Association of Canada, $662 \mathrm{p}$

Jemielita, R.A., Davis, D.W., and Krogh, T.E., 1990, U-Pb evidence for Abitibi gold mineralization postdating greenstone magmatism and metamorphism: Nature, v. 346, p. 831-834.

Jensen, L.S., and Barton, M.D., 2000, Gold deposits related to alkaline magmatism: Reviews in Economic Geology, v. 13, p. 279-314.

Jugo, P.J., 2009, Sulfur content at sulfide saturation in oxidized magmas: Geology, v. 37, p. 415-418. 
Kerrich, R., 1993, Perspectives on genetic models for lode gold deposits: Mineralium Deposita, v. 28, p. 362-365.

Kirkland, C.L., Spaggiari, C.V., Smithies, R.H., Wingate, M.T.D., Belousova, E.A., Gréau, Y., Sweetapple, M.T., Watkins, R., Tessalina, S., and Creaser, R., 2015, The affinity of Archean crust on the Yilgarn-Albany-Fraser orogen boundary: Implications for gold mineralisation in the Tropicana zone: Precambrian Research, v. 266, p. 260-281.

Laurent, O., Martin, H., Moyen, J.F., and Doucelance, R., 2014, The diversity and evolution of late-Archean granitoids: Evidence for the onset of "modern-style" plate tectonics between 3.0 and 2.5 Ga: Lithos, v. 205, p. 208-235.

Lauzière, K., 1989, Environnement géologique et minéralisation aurifère à la mine Bachelor, Desmaraisville, Québec: MSc thesis, Université du Québec à Chicoutimi, $181 \mathrm{p}$.

Lavigne, J., 2011, NI 43-101 Technical report on the Golden Arrow property, Ontario: Ressources Murgor Inc, http://www.sedar.com, 77 p.

Leclerc, F., Bédard, J.H., Harris, L., Goulet, N., Roy, P., and Houle, P., 2011, Tholeiitic to calc-alkaline cyclic volcanism in the Roy Group, Chibougamau area, Abitibi Greenstone Belt-revised stratigraphy and implications for VHMS exploration: Geological Survey of Canada Contribution 20100254; Ministère des Ressources naturelles et de la Faune Contribution 84392010-2011-17; Canadian Journal of Earth Sciences, v. 48, p. 661-694.

Leclerc, F., Harris, L.B., Bédard, J.H., van Breemen, O., and Goulet, N., 2012, Structural and stratigraphic controls on magmatic, volcanogenic, and shear zone-hosted mineralization in the Chapais-Chibougamau mining camp, northeastern Abitibi, Canada: Economic Geology, v. 107, p. 963-989.

Lin, S., and Beakhouse, G.P., 2013, Synchronous vertical and horizontal tectonism at late stages of Archean cratonization and genesis of Hemlo gold deposit, Superior craton, Ontario, Canada: Geology, v. 41, p. 359-362.

Manning, D.A.C., 1981, The effect of fluorine on liquidus phase relationships in the system quartz-Ab-Or with excess water at $1 \mathrm{~kb}$ : Contributions to Mineralogy and Petrology, v. 76, p. 206-215.

Matsuhisa, Y., Goldsmith, J.R., and Clayton, R.N., 1979, Oxygen isotopic fractionation in the system quartz-albite-anorthite-water: Geochimica et Cosmochimica Acta, v. 43, p. 1131-1140.

McCuaig, T.C., and Kerrich, R., 1998, P-T-t-deformation-fluid characteristics of lode gold deposits: Evidence from alteration systematics: Ore Geology Reviews, v. 12, p. 381-453.

McCuaig, T.C., Behn, M., Stein, H., Hagemann, S.G., McNaughton, N.J., Cassidy, K.F., Champoin, D., and Wyborn, L., 2001, The Boddington gold mine: A new style of Archean Au-Cu deposit [ext. abs.]: AGSO, Geoscience Australia Record 2001/37, p. 453-455.

McDonough, W.F., and Sun, S.s., 1995, The composition of the Earth: Chemical Geology, v. 120 , p. 223-253.

Metrich, N., and Clocchiatti, R., 1996, Sulfur abundance and its speciation in oxidized alkaline melts: Geochimica et Cosmochimica Acta, v. 60, p. $4151-4160$.

Midra, R., 1989, Géochimie des laves de la Formation d’Obatogamau (Bande sud de la ceinture archéenne Chibougamau-Matagami) Québec, Canada: M.Sc thesis, Université du Québec à Chicoutimi, 115 p.

Miller, C.F., McDowell, S.M., and Mapes, R.W., 2003, Hot and cold granites? Implications of zircon saturation temperatures and preservation of inheritance: Geology, v. 31, p. 529-532.

Monecke, T., Kempe, U., Trinkler, M., Thomas, R., Dulski, P., and Wagner, T., 2011, Unusual rare earth element fractionation in a tin-bearing magmatic-hydrothermal system: Geology, v. 39, p. 295-298.

Morasse, S., 1988, Geological setting and evolution of the Lac Shortt gold deposit, Waswanipi, Quebec, Canada: MSc thesis, Kingston, Ontario, Queen's University, $221 \mathrm{p}$.

Mungall, J.E., 2002, Roasting the mantle: Slab melting and the genesis of major $\mathrm{Au}$ and $\mathrm{Au}-\mathrm{rich} \mathrm{Cu}$ deposits: Geology, v. 30, p. 915-918.

Nadeau, O., Stevenson, R., and Jébrak, M., 2014, The Archean magmatichydrothermal system of Lac Shortt (Au-REE), Abitibi, Canada: Insights from carbonate fingerprinting: Chemical Geology, v. 387, p. 144-156.

Pokrovski, G.S., and Dubessy, J., 2015, Stability and abundance of the trisulfur radical ion in hydrothermal fluids: Earth and Planetary Science Letters, v. 411, p. 298-309.

Pokrovski, G.S., and Dubrovinsky, L.S., 2011, The $\mathrm{S}_{3}$-ion is stable in geological fluids at elevated temperatures and pressures: Science, v. 331, p. $1052-1054$

Prud'homme, N., 1990, Caracterisation petrographique et geochimique de la carbonatite et de la syenite de la mine Lac Shortt, Petrographic and geochemical characterization of the carbonatite and of the syenite of the Shortt Lake mine, Canada: MSc thesis, Université du Québec à Chicoutimi, $78 \mathrm{p}$.

Pupin, J.P., 1980, Zircon and granite petrology: Contributions to Mineralogy and Petrology, v. 73, p. 207-220.

Pupin, J.P., and Turco, G., 1972, Le zircon accessoire en géothermométrie: C.R. Académie des Sciences Paris, v. 274 (D), p. 2121-2124.

Rasouli, J., and Shirzadi, L., 2017, Chemical composition of biotite as a guide to petrological characteristics in the Jebal-e-Barez plutonic complex, SE Iran [ext. abs.]: Geoconvention, Calgary, Canada, May 15-19, 2017, 5 p. (https://www.geoconvention.com/home/abstract-archives/2017-abstracts html)

Robert, F., 2001, Syenite-associated disseminated gold deposits in the Abitibi greenstone belt, Canada: Mineralium Deposita, v. 36, p. 503-516.

Rowins, S.M., Cameron, E.M., Lalonde, A.E., and Ernst, R.E., 1993, Petrogenesis of the late Archean syenitic Murdock Creek Pluton, Kirkland Lake, Ontario; evidence for an extensional tectonic setting: The Canadian Mineralogist, v. 31, p. 219-244

See, J., 1994, Lanalyse des inclusions fluides et magmatiques des dépôts aurifères dans la région du Lac Shortt, Abitibi, Québec: l'interprétation thermodynamique et métallogénétique du rôle des fluides minéralisants à l'Archéen, Chicoutimi: PhD thesis, Université du Québec à Chicoutimi, $281 \mathrm{p}$.

Seward, T.M., and Barnes, H.L., 1997, Metal transport by hydrothermal ore solutions, in Barnes, H.L., ed., Geochemistry of hydrothermal ore deposits: John Wiley, p. 435-486.

Shabani, A.A.T., Lalonde, A.E., and Whalen, J.B., 2003, Composition of biotite from granitic rocks of the Canadian Appalachian orogen: A potential tectonomagmatic indicator? The Canadian Mineralogist, v. 41, p. 1381-1396.

Sharma, K.N.M., and Lacoste, P., 1981, Carte géologique Gand (SW) et Lespérance $(\mathrm{NW})$ : Ministère de l'Énergie et des Ressources, Gouvernement du Québec, DP 852, scale 1:20,000, 1 p.

Sharma, K.N.M., and Lauzière, K., 1983, Géologie de la région de Desmaraisville. Carte manuscrite avec notes marginales: Ministère de l'Énergie et des Ressources, Gouvernement du Québec, DP 84-10, scale 1:20,000, 2 p.

Sharma, K.N.M., Gobeil, A., and Mueller, W., 1987, Stratigraphie de la région du lac Caopatina: Ministère de l'Énergie et des Ressources, Gouvernement du Québec, Report MB 87-16, 16 p.

Sillitoe, R.H., 1991, Intrusion-related gold deposits, in Gold metallogeny and exploration: Boston, Springer, p. 165-209, doi.org/10.1007/ 978-1-4613-0497-5_6.

2000, Gold-rich porphyry deposits: Descriptive and genetic models and their role in exploration and discovery: Reviews in Economic Geology, v. 13, p. $315-345$.

2010, Porphyry copper systems: Economic Geology, v. 105, p. 3-41.

Smithies, R.H., and Champion, D.C., 1999, Late Archaean felsic alkaline igneous rocks in the Eastern Goldfields, Yilgarn craton, Western Australia: A result of lower crustal delamination?: London, Journal of the Geological Society, v. 156 , p. 561-576.

Sun, W., Huang, R.-f., Li, H., Hu, Y.-b., Zhang, C.-c., Sun, S.-j., Zhang, L.-p., Ding, X., Li, C.-y., Zartman, R.E., and Ling, M.-x., 2015, Porphyry deposits and oxidized magmas: Ore Geology Reviews, v. 65, Part 1, p. 97-131.

Sutcliffe, R.H., Barrie, C.T., Burrows, D.R., and Beakhouse, G.P., 1993, Plutonism in the southern Abitibi Subprovince; a tectonic and petrogenetic framework: Economic Geology, v. 88, p. 1359-1375.

Thurston, P.C., Ayer, J.A., Goutier, J., and Hamilton, M.A., 2008, Depositional gaps in Abitibi greenstone belt stratigraphy: A key to exploration for syngenetic mineralization: Economic Geology, v. 103, p. 1097-1134.

Trudel, P., and Sauvé, P., 1992, Synthèse des caractéristiques géologiques des gisements d'or du district de Malartic: Ministère de l'Énergie et des Ressources, Gouvernement du Québec, Report MM89-04, 126 p.

Von Raumer, J.F., Finger, F., Veselá, P., and Stampfli, G.M., 2014, Durbachites-vaugnerites-a geodynamic marker in the central European Variscan orogen: Terra Nova, v. 26, p. 85-95.

Webster, J.D., Thomas, R., Veksler, I., Rhede, D., Seltmann, R., and Forster, H.-J., 1998, Late-stage processes in P-or F-rich granitic magmas: Acta Universitatis Carolinae-Geologica, v. 42, p. 181-188.

Williams-Jones, A.E., and Migdisov, A.A., 2014, Experimental constraints on the transport and deposition of metals in ore-forming hydrothermal systems: Society of Economic Geologists, Special Publication 18, p. 77-95.

Winchester, J.A., and Floyd, P.A., 1977, Geochemical discrimination of different magma series and their differentiation products using immobile elements: Chemical Geology, v. 20, p. 325-343. 
Wones, D.R., and Eugster, H.P., 1965. Stability of biotite: Experiment, theory, and application. The American Mineralogist, v. 50, p. 1228-1272.

Yardley, B.W.D., and Bodnar, R.J., 2014, Section 2. Crustal fluid compositions: The basics: Geochemical Perspectives, v. 3, p. 20-53.

Zajacz, Z., Seo, J.H., Candela, P.A., Piccoli, P.M., Heinrich, C.A., and Guillong, M., 2010, Alkali metals control the release of gold from volatile-rich magmas: Earth and Planetary Science Letters, v. 297, p. 50-56.
Zhou, T., Wang, S., Fan, Y, Yuan, F., Zhang, D., and White, N.C., 2015, A review of the intracontinental porphyry deposits in the Middle-Lower Yangtze River Valley metallogenic belt, Eastern China: Ore Geology Reviews, v. 65, p. $433-456$. 